\title{
State Leadership Development Policies An Analysis of 50 States and Territories
}

\author{
Bobbi Newman \\ University of Pennsylvania \\ Jonathan Supovitz \\ University of Pennsylvania \\ Stephen Prociw \\ Robert Hull \\ Gregory Collins
}

Follow this and additional works at: https://repository.upenn.edu/cpre_researchreports

Part of the Educational Leadership Commons

\section{Recommended Citation}

Newman, Bobbi; Supovitz, Jonathan; Prociw, Stephen; Hull, Robert; and Collins, Gregory. (2017). State Leadership Development Policies An Analysis of 50 States and Territories. CPRE Research Reports. Retrieved from https://repository.upenn.edu/cpre_researchreports/95 


\title{
State Leadership Development Policies An Analysis of 50 States and Territories
}

\begin{abstract}
State education systems to support leadership development have received relatively scant attention and resources, despite the demonstrated importance of leadership to school improvement. This need spurred the National Association of State Boards of Education (NASBE) to form a study group with its members and partner with the Consortium for Policy Research in Education (CPRE) to examine the problem from a state policy perspective; to offer a framework, guidance, and resources to help states develop and keep effective leaders; provide examples of practices for states; and share insights from partner organizations. The report, Successful Leaders for Successful Schools: Building and Maintaining a Quality Workforce, details findings that emerged from this work. As a companion piece to this work, State Leadership Development Policies -An Analysis of 50 States and Territories, presents a comprehensive picture of school leadership development policies across all 50 states and US territories. CPRE Researchers Bobbi Newman, Jonathan Supovitz, and Greg Collins, in collaboration with NASBE's Robert Hull and Stephen Prociw, produced an interactive report that seeks to operationalize the framework developed for state education agencies to improve the school leadership pipeline.

Researchers interviewed state board members and staff members from state education agencies to learn about their states' school leadership development policies and practices. Data collection questions focused on identifying the organizational and individual supports that states have established. State Leadership Development Policies -An Analysis of 50 States and Territories provides a wealth of information for state leaders interested in learning about a sample of each state's policies and programs that support the school leadership pipeline.

\section{Keywords}

leadership development

Disciplines

Education | Educational Leadership
\end{abstract}




\section{State Leadership Development Policies}

An Analysis of 50 States and Territories

Bobbi Newman

Stephen Prociw

Robert Hull

Gregory Collins

Jonathan Supovitz

\section{PennGSE}




\section{State Leadership Development Policies}

\section{An Analysis of 50 States and Territories}

\section{Introduction}

State systems to support leadership development have received relatively scant attention and resources, despite the demonstrated importance of leadership to school improvement. This need spurred the National Association of State Boards of Education (NASBE) to partner with the Consortium for Policy Research in Education (CPRE) to examine the problem from a state policy perspective; to offer a framework, guidance, and resources to help states develop and keep effective leaders; provide examples of practices for states; and share insights from partner organizations. The report, Successful Leaders for Successful Schools: Building and Maintaining a Quality Workforce, details findings that emerged from this work.

To guide state boards of education (SBEs) as they consider policy actions around leadership development, NASBE study group members in concert with CPRE developed the State-Level Policy Development Framework (see figure). The framework is a conceptual way of thinking about policy development. It is intended to help state board members identify the levers and processes that their board needs to consider for sound policymaking and the method for achieving action around the key levers. The framework is anchored in leadership standards and supported by data monitoring of the leadership development process for school leaders.

Once a state board has established strong leadership standards, the work of implementation begins. Leadership standards are operationalized in two forms: organizational and individual supports. Support for the operationalization of standards comes in two forms. First, states may develop a set of organizational supports for leadership standards, which include a range of systems and structures to facilitate leadership development (the left side of the framework). Second, states may develop a set of supports to facilitate the capacity building of individual leaders (the right side).

Organizational supports are systems and structures that facilitate leadership development: program approval, licensure, partnerships, and sponsorships. Program approval and licensure articulate a pathway for individuals to enter the educational leadership workforce. Program approval and licensure are inextricably linked, in that most SBEs establish both the approval process for institutional programs that prepare leaders and the licensure requirements for leaders.

It is essential that the leadership standards form the basis of preparation programs and the licensure process. Partnerships and sponsorships provide the conduit through which candidates can better access those pathways.

Individual supports are distinct from organizational supports in that they are direct services to future and current school leaders. States may develop educational leaders by recruiting professionals into the field, by developing their own leadership preparation programs, and by making decisions to license and/ or certify individual leaders. States may also directly support current or future leaders through the direct delivery of capacity-building experiences. They may build mechanisms to directly evaluate individual educational leaders. The small circle within the framework serves as a reminder of the interrelationship of certification, professional learning, and evaluation.

Finally, data should guide a coherent state leadership development system. To that end, states should collect and analyze a range of data indicators of leadership preparation and practice to track ongoing improvement of leadership capacity. State longitudinal data systems and data warehousing sources in each state are rich sources of information. Two primary data sets should be considered. First, data on student populations and migrations will inform boards of where leaders will be needed. Second, information on current licensure applications and program enrollment will indicate where current and future leaders are located.

This document seeks to operationalize the framework with data collected from a comprehensive study of school leadership development policies across all 50 states and US territories. Researchers from CPRE, in collaboration with NASBE, interviewed state board members and staff members from state education agencies to learn about their states' school leadership development policies and practices. Data collection questions focused on identifying the organizational and individual supports that states have established.

Findings revealed that certain states have started work in these areas, 
exemplified in a set of practices identified as reflecting components of the framework. While state boards may or may not have the authority to set policy in a given area, all have the power to convene and question. The governance structure and levels of policy authority across states vary widely and affect areas of the framework within the purview of each state board of education. No state has the whole framework in place, but many states have practices that reflect the framework, and thus they are included in the report. Findings include a limited emphasis on principal evaluation systems since many states, in particular those states that did not participate in federal Race to the Top grants, are still in the pilot phase of their principal evaluation systems. However, data collected revealed a majority of states are focusing some of their resources for principal professional learning on the processes and systems needed for principals to implement the state's teacher evaluation systems. This emphasis seems to be at the expense of developing school leaders' other professional learning needs such as leadership development and developing instructional leadership capacity. The analysis revealed that states have experienced varying evolutions of the components of their leadership development systems. As stated previously, every state has a different context and governance structure, the division of authority within the state education system will vary widely. While some state boards of education have full authority over all areas of the leadership development spectrumestablishing principal standards, setting the criteria and approval process for principal preparation programs, issuing licenses to principals, outlining the evaluation procedures used to measure principal effectiveness, and prescribing ongoing professional learning requirements for principals-there are others with a limited scope of authority or only advisory roles in many of these areas.

Also included in the findings are administrative data from the National Center for Education

\section{With the passage of the Every Student Succeeds Act in 2015, states are encouraged to continue to develop both organizational and individual supports needed to develop leadership capacity.}

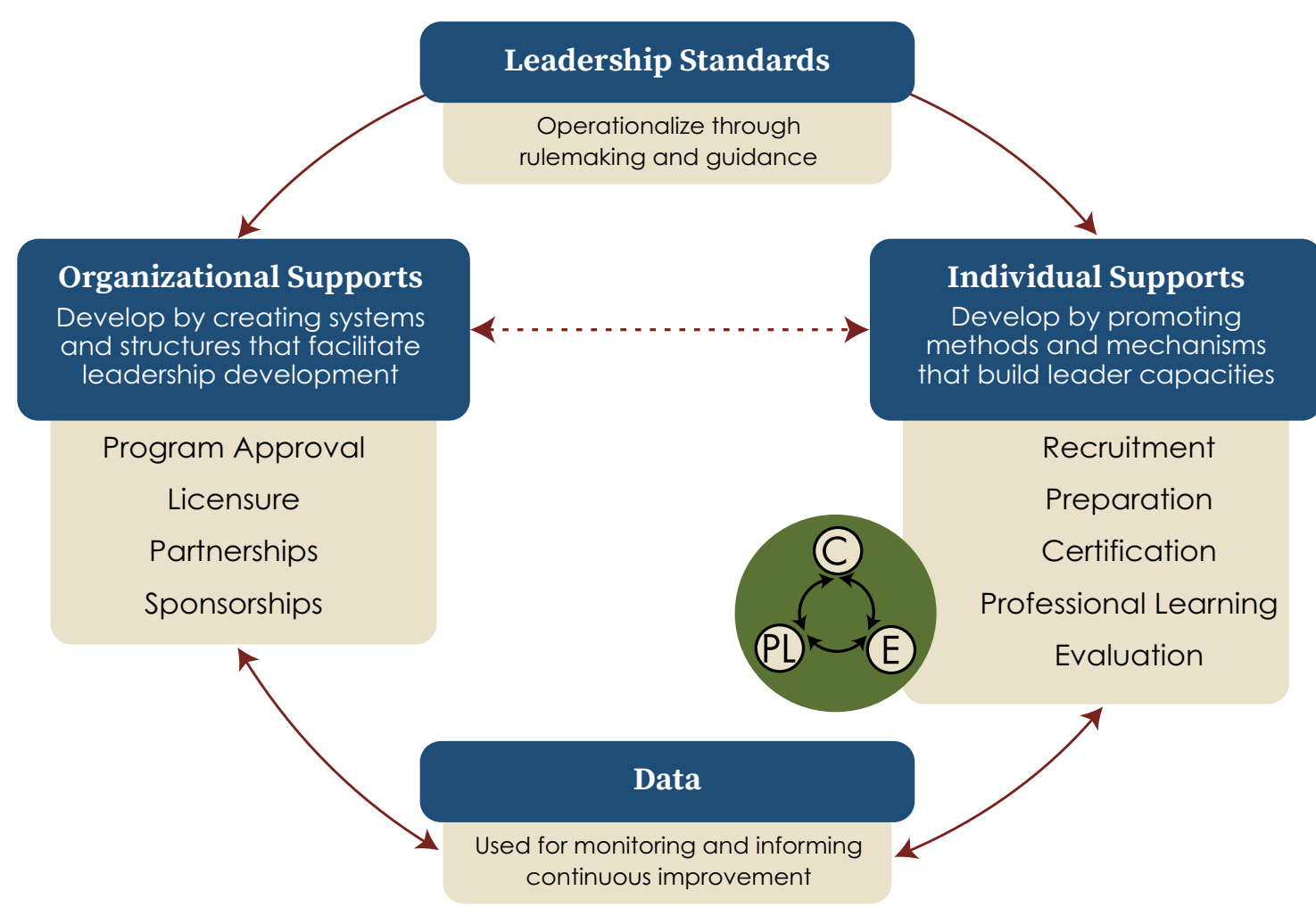

CPRE/NASBE 9/15/15

Statistics (NCES) Common Core of Data (CCD). These data were used to construct charts of school districts by locale type for each state. The charts provide data on the types of school districts such as urban, suburban, town, and rural for each state. Data reveal that over 35 states have 45 percent or greater of their districts identified as rural. School leaders in these districts may need different individual or organizational supports than their counterparts in urban or suburban districts.
The data described above is presented in an interactive map. The data highlights the work of states building capacity through partnerships, strategic plans, and revisions of their leadership preparation programs. 
As one state leader commented:

We really are digging into our school leader and administrator policies. This is unique for us. We had the rules for [principal] evaluation and a little different federal landscape at the time. This is sort of us coming at a different direction since we are not accustomed to developing policies that are less by force and more by our needs and actions.

With the passage of the Every Student Succeeds Act in 2015, states are encouraged to continue to develop both organizational and individual supports needed to develop leadership capacity. This guide captures state practices in each area of the State-Level Policy Development Framework in order to help states learn about other states' efforts in supporting leadership development.

\section{References}

Every Student Succeeds Act, 2015, Pub. L. No. 114-95, 114 th Cong., 1st. Sess. (December 10, 2015). Congress.gov

Hull, Robert, Jonathan Supovitz, Bobbi Newman, and Stephen Prociw. 2015. "Successful Leaders for Successful Schools: Building and Maintaining a Quality Workforce: Report of the NASBE Leadership Development Study Group." Alexandria, VA: NASBE, http://www.nasbe.org/study-group-report/ successful-leaders-for-successful-schools-building-and-maintaining-a-qualityworkforce/

\section{Sugessted Citation}

Newman, B., Prociw, S., Hull, R., Collins, G., \& Supovitz, J. (2017). State Leadership Development Policies -An Analysis of 50 States and Territories. (RR 17-1). Philadelphia, PA: Consortium for Policy Research in Education.

\section{How to Use This Document}

The entire report can be downloaded as an interactive PDF or for print using Adobe Acrobat.

To enhance your reading experience, go to File $>$ Preferences $>$ Page Display $>$ Page Layout and select Single Page Continuous from the drop-down menu.

\section{Interactive PDF}

Click on links throughout this report and on our interactive map to see data for each state.

In addition, NASBE's State Policy Database contains a comprehensive collection of state policies that affect educator effectiveness. The database includes policies on educator preparation and licensure, educator performance evaluation, educator professional growth and development, and professional learning standards and requirements. The online database can be searched by policy topic and by state. 


\section{State Practices by Framework Component}

The State-Level Policy Development Framework is a conceptual way of thinking about the levers and processes that state boards need to consider for sound policymaking (see table below). The framework comprises organizational and individual supports and the method for achieving action around key levers and processes. The framework is anchored in leadership standards and data monitoring of the leadership development process for school leaders. For each practice that states shared, researchers categorized the practice as either organizational, individual, and/or data supports.

Introduction

How to Use This Document Interactive Map

State Profiles

Methods

About Consortium for Policy Research in Education (CPRE)

About National Association of State Boards of Education

\begin{tabular}{|c|c|c|c|c|c|c|c|c|c|c|}
\hline \multirow[b]{2}{*}{ State } & \multicolumn{4}{|c|}{ Organizational Supports } & \multicolumn{5}{|c|}{ Individual Supports } & \multirow[t]{2}{*}{ Data } \\
\hline & 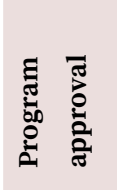 & 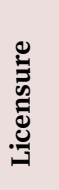 & 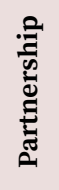 & 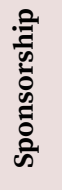 & 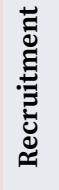 & 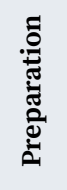 & 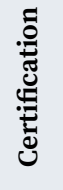 & 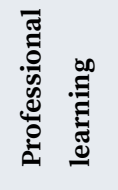 & 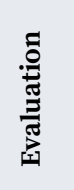 & \\
\hline Alabama & & & & $\checkmark$ & & $\checkmark$ & & & & \\
\hline Alaska & & & & 4 & & & & $s$ & & \\
\hline Arizona & & & 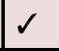 & & 4 & & & & & \\
\hline Arkansas & & & 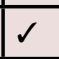 & & 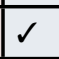 & & & $\checkmark$ & & \\
\hline California & & & & & & $\checkmark$ & & & & $\checkmark$ \\
\hline Colorado & & & & & 1 & & & & & 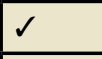 \\
\hline Connecticut & 1 & & 1 & & & & & & & \\
\hline $\mathrm{DC}$ & & & & & 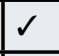 & & & & & \\
\hline Delaware & & & & & & & & $\checkmark$ & $d$ & \\
\hline Florida & & & & & & & $\checkmark$ & & & \\
\hline Georgia & $\checkmark$ & & & & & $\checkmark$ & & & & \\
\hline Guam & & & & & 1 & & & $s$ & & \\
\hline Hawaii & & & & & 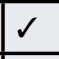 & & & $\checkmark$ & & \\
\hline Idaho & & & & & & & & $\checkmark$ & & \\
\hline Illinois & & & & & & & 1 & 2 & & $s$ \\
\hline Indiana & & & & $\checkmark$ & & $\checkmark$ & & & & \\
\hline Iowa & & & & 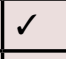 & & & & 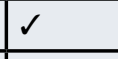 & & \\
\hline Kansas & & & $\checkmark$ & & & & & & & \\
\hline
\end{tabular}


$\underline{\text { Introduction }}$

How to Use This Document

Interactive Map

State Profiles

Methods

About Consortium for Policy Research in Education (CPRE)

About National Association of State Boards of Education

\begin{tabular}{|c|c|c|c|c|c|c|c|c|c|c|}
\hline \multirow[b]{2}{*}{ State } & \multicolumn{4}{|c|}{ Organizational Supports } & \multicolumn{5}{|c|}{ Individual Supports } & \multirow[t]{2}{*}{ Data } \\
\hline & 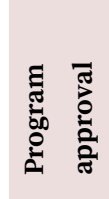 & 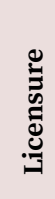 & 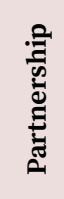 & 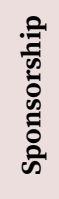 & 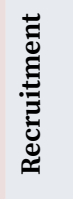 & 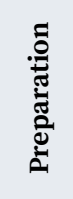 & 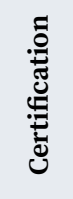 & 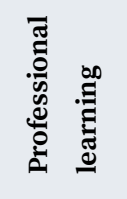 & 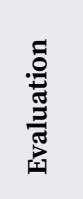 & \\
\hline Kentucky & & & 8 & & & & & 5 & & \\
\hline Louisiana & & & & & & & & 5 & & \\
\hline Maine & & & 5 & & & & & . & & \\
\hline Maryland & & & & & 5 & & & 5 & & \\
\hline Massachusetts & 8 & 2 & & & & & & & & \\
\hline Michigan & & 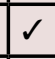 & & & & & & . & & $s$ \\
\hline Minnesota & & & 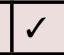 & & & & & & & \\
\hline Mississippi & & & & & $\Delta$ & & & 6 & & \\
\hline Missouri & 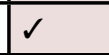 & 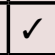 & & & & & & & & \\
\hline Montana & & & 6 & & & & & & & \\
\hline Nebraska & & & & & & & & & 2 & \\
\hline Nevada & & & & & & & & 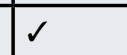 & & \\
\hline New Hampshire & & & & & & & & 5 & & \\
\hline New Jersey & & & 6 & & & & & & & \\
\hline New Mexico & & & & 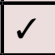 & & 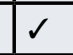 & & & & \\
\hline $\begin{array}{l}\text { New York } \\
\end{array}$ & & & 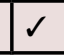 & & & 6 & & & & \\
\hline North Carolina & & & 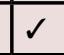 & & & 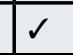 & & & & \\
\hline North Dakota & & & & & & & & & 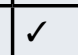 & \\
\hline
\end{tabular}


Introduction

How to Use This Document Interactive Map

State Profiles

Methods

About Consortium for Policy Research in Education (CPRE)

About National Association of State Boards of Education

\begin{tabular}{|c|c|c|c|c|c|c|c|c|c|c|}
\hline \multirow[b]{2}{*}{ State } & \multicolumn{4}{|c|}{ Organizational Supports } & \multicolumn{5}{|c|}{ Individual Supports } & \multirow[t]{2}{*}{ Data } \\
\hline & 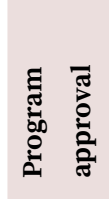 & 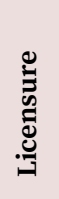 & 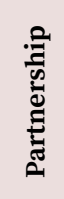 & 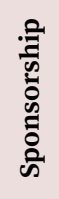 & 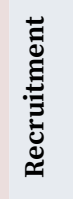 & 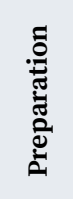 & 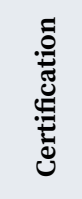 & 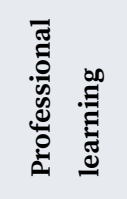 & 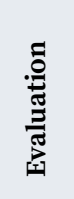 & \\
\hline $\begin{array}{l}\text { Northern } \\
\text { Mariana Islands }\end{array}$ & & & & & & & & I & & \\
\hline Ohio & & & 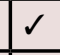 & & & & & & & \\
\hline Oklahoma & 2 & & 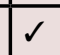 & & & & & & & \\
\hline Oregon & & 2 & & & & 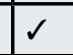 & & & & \\
\hline Pennsylvania & & & & & & & & 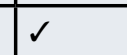 & 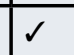 & \\
\hline Rhode Island & 2 & & & & & 2 & & & & \\
\hline South Carolina & & & & & & & a & & 2 & \\
\hline South Dakota & 2 & & & & & & & & & \\
\hline Tennessee & & & & & & 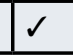 & & 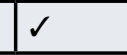 & & \\
\hline Texas & & & 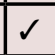 & & & & & & & 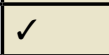 \\
\hline Utah & & & & & & & & $\sigma$ & & \\
\hline $\begin{array}{l}\text { Vermont } \\
\end{array}$ & & & 2 & & & & & & & \\
\hline $\begin{array}{l}\text { Virginia } \\
\text { a }\end{array}$ & & & & & & & 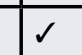 & & & \\
\hline Washington & & 2 & & 2 & & & & & & \\
\hline West Virginia & & & 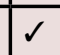 & & & & & 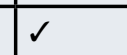 & & \\
\hline Wisconsin & & & & & & $\mathrm{s}$ & & & $\checkmark$ & $\checkmark$ \\
\hline Wyoming & & & $\checkmark$ & & & & & & & \\
\hline
\end{tabular}


WA

$\underline{M I}$

$\underline{O R}$

$\underline{\mathbb{D}}$

$\underline{\text { wY }}$

NV

$\underline{C A}$

$\underline{A K}$

HI

AZ $\quad$ NM
NE

ND

$\underline{S D}$

$\underline{\mathrm{KS}}$

MN

$\underline{w 1}$

Ml

VT $\mathrm{NH}$

NY $\frac{M A}{C T} \quad \underline{R I}$

IA

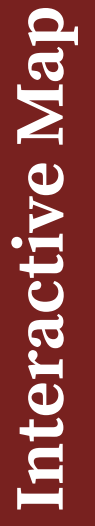

IX

$\underline{M O}$

$\underline{I} \quad \underline{\mathbb{N}}$

\begin{tabular}{ll} 
& PA \\
$\mathrm{OH}$ & $\mathrm{MD}$ \\
\hline
\end{tabular}

NJ

DE

DC

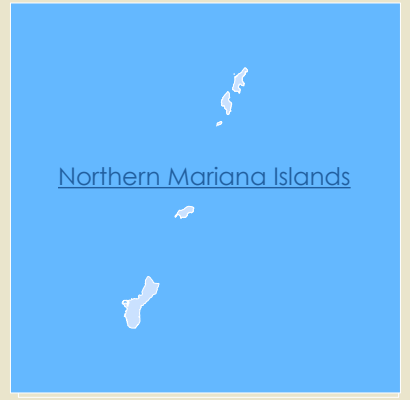

$\underline{L A}$

$\underline{K Y}$

IN

$\underline{A R}$

MS

$\underline{A L}$

GA

VA

NC

$\underline{\mathrm{sC}}$

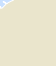

$\underline{F L}$

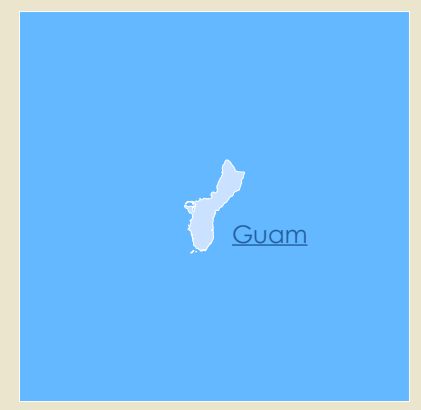

\section{State Profiles}

Alabama

Alaska

Arizona

Arkansas

California

colorado

$\underline{\text { Connecticut }}$

$\frac{\text { District of }}{\underline{\text { Columbia }}}$
Delaware
Florida
Georgia
Guam
$\underline{\text { Hawaii }}$

Idaho

llinois

Indiana

lowa

Kansas

Kentucky

Lovisiana

Maine
Maryland
Massachusetts
Michigan
Minnesota
Mississippi
Missouri

Montana
Nebraska
Nevada
$\frac{\text { New }}{\text { Hampshire }}$
New Jersey
New Mexico

New York

North Carolina

North Dakota

Northern

Mariana

Islands

Ohio

Oklahoma

$\begin{array}{ll}\underline{\text { Oregon }} & \underline{\text { Utah }} \\ \underline{\text { Pennsylvania }} & \underline{\text { Vermont }} \\ \underline{\text { Rhode Island }} & \underline{\text { Virginia }} \\ \underline{\text { South Carolina }} & \underline{\text { Washington }} \\ \underline{\text { South Dakota }} & \underline{\text { West Virginia }} \\ \underline{\text { Tennessee }} & \underline{\text { Wisconsin }} \\ \underline{\text { Texas }} & \underline{\text { Wyoming }}\end{array}$




\section{Schools: 1,517}

Districts: 137

\section{School Districts by Locale}

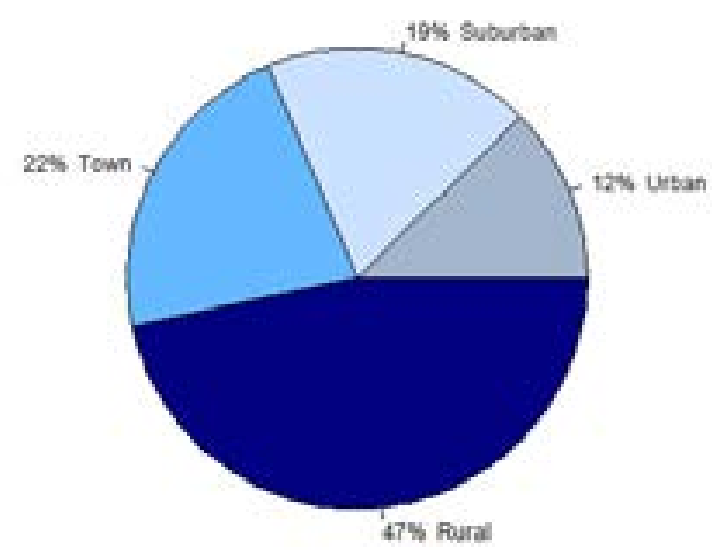

Introduction

How to Use This Document

Interactive Map

\section{State Profiles}

Methods

About Consortium for Policy Research in Education (CPRE)

About National Association of State Boards of Education

\section{Alabama}

In the state of Alabama, standard-setting authority resides with the state board of education. The school leadership standards as of October 2015 are the Alabama Instructional Leader Standards.

\section{Leadership development practice:}

The purpose of the Alabama Principal Candidate Semester Residency is to improve student achievement and schools by developing school leaders. The residency program is funded on an annual basis to help achieve the goals of Alabama's Plan 2020. Plan 2020 states that by the year 2020, every school in Alabama is led by a well-prepared, supported, and effective leader. The program funds candidates for a semester of paid leave to complete the residency program and receive mentoring by a skilled administrator or principal. The residency program encourages and strengthens the development of partnerships between local school districts and universities and supports leadership practice that aligns to the Alabama Standards for Instructional Leaders.

State-Level Policy Development Framework component: Sponsorship

For more information visit: http://alex.state.al.us/leadership/pcrp.htm

\section{Leadership development practice:}

The Alabama New Principal Mentoring (ANPM) Program is a two-year program for all new school leaders. Each principal receives a trained mentor as a leadership coach. The mentor helps the new principal create a development plan and a "map" of various learning activities to help the new principal speed his or her orientation to the job and facilitate professional growth based upon the Alabama Continuum for Instructional Leader Development. The district and state provide training and support to the mentors.

State-Level Policy Development Framework component: Preparation

For more information visit: http://alex.state.al.us/leadership/anpm.html 
Schools: 507

Districts: 53

\section{School Districts by Locale}

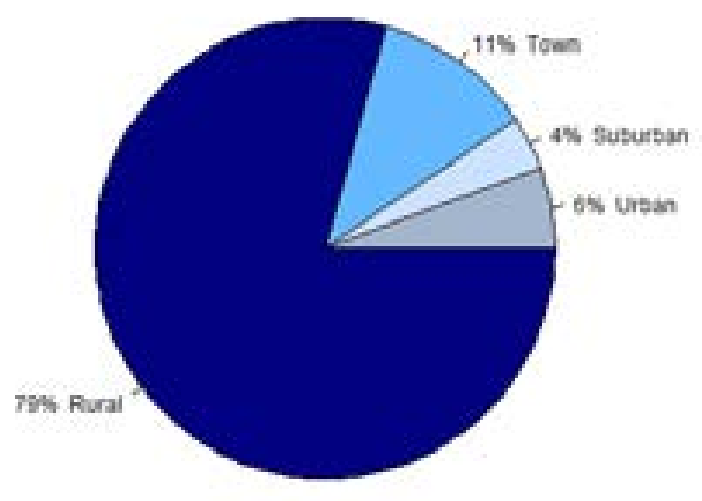

Introduction

\section{How to Use This Document}

Interactive Map

\section{State Profiles}

Methods

About Consortium for Policy Research in Education (CPRE)

About National Association of State Boards of Education

\section{Alaska}

\section{Return to Interactive Map}

In the state of Alaska, the standard setting authority resides with the state board of education. The school leadership standards as of October 2015 are the Standards for Alaska's Administrators.

\section{Leadership development practice:}

The Alaska Department of Education and Early Development supports the Alaska School Leadership Institute's (ASLI) Institute for Rural and Small School Leaders. The initiative centers on an annual conference hosted by department in collaboration with other organizations in the state. Travel costs for principals to attend the conference is paid for in part by state dollars.

State-Level Policy Development Framework component: Sponsorship

For more information visit: http://www.asdn.org/alaska-school-leadership-institute-3/

\section{Leadership development practice:}

The Alaska Department of Education and Early Development offers web-based, interactive training courses to assist principals in their professional learning. The on-line courses provide opportunities for principals serving in remote districts an opportunity to participate in on-going training and professional learning.

State-Level Policy Development Framework component: Professional Learning

For more information visit: https://www.eed.state.ak.us/ELearning/

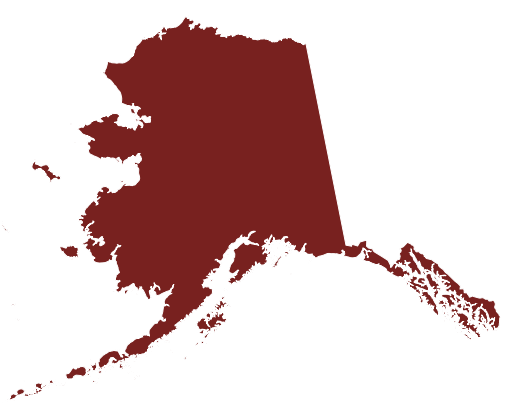




\section{Arizona}

Schools: 2,281

Districts: 225

\section{School Districts by Locale}

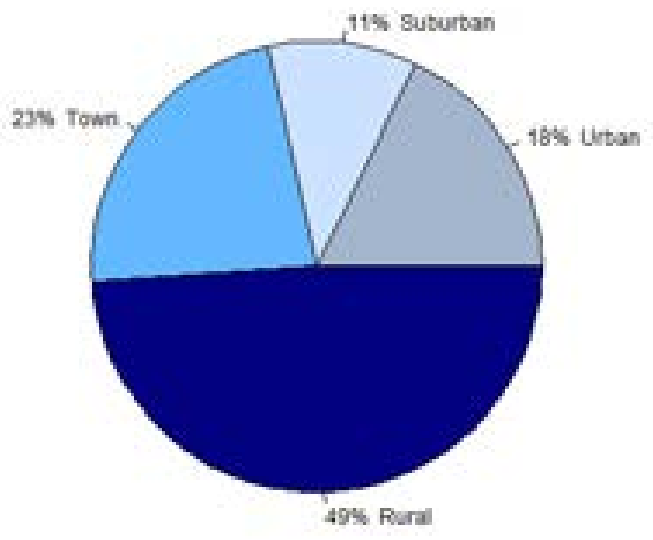

Introduction

\section{How to Use This Document}

Interactive Map

\section{State Profiles}

Methods

About Consortium for Policy Research in Education (CPRE)

About National Association of State Boards of Education
In the state of Arizona, the standard setting authority resides with the state board of education. The school leadership standards as of October 2015 are the ISLLC 2008 Standards.

\section{Leadership development practice:}

Former Arizona principals and principal supervisors along with Arizona State University faculty offers a fifteen-month principal development program in which Arizona school districts partner with ASU in developing principal pipelines within the District. The program to focused on developing the skills of assistant principals to foster their leadership skills.

State-Level Policy Development Framework component: Recruitment

For more information visit: https://education.asu.edu/sites/default/files/ileadaz res fags 2015.pdf

\section{Leadership development practice:}

Arizona Department of Education in partnership with the National Association of Secondary School Principals and Learning Forward designed the Learning Leaders program to strengthen and expand principal professional learning to support student outcomes. The Learning Leaders program will support current and aspiring principals to model the use of data for effective instructional leadership.

\section{State-Level Policy Development Framework component: Partnership}

For more information visit: http://www.azed.gov/highly-qualified-professionals/educator-excellence-overview/ learning-leaders-for-learning-schools/ 


\section{Arkansas}

Schools: 1,101

Districts: 237

School Districts by Locale

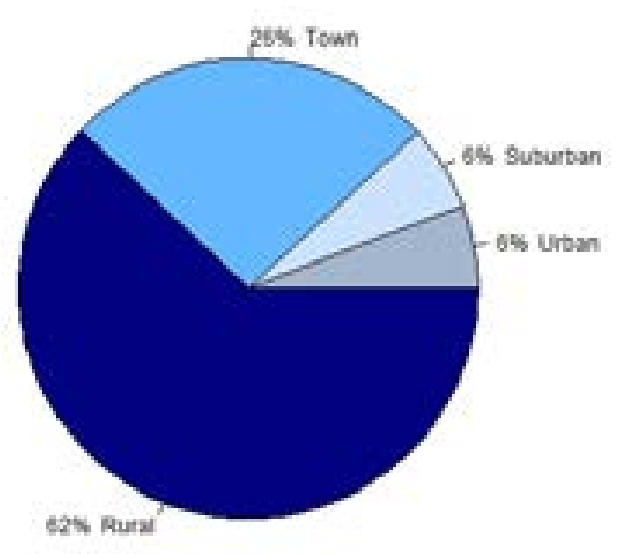

$\underline{\text { Introduction }}$

\section{How to Use This Document}

Interactive Map

\section{$\underline{\text { State Profiles }}$}

Methods

About Consortium for Policy Research in Education (CPRE)

About National Association of State Boards of Education
In the state of Arkansas, the standard setting authority resides with the state board of education. The school leadership standards as of October 2015 are the Standards for School Administrators in Arkansas.

\section{Leadership development practice:}

The purpose of the Master Principal Program is to provide training and opportunities to expand the knowledge base and leadership skills of public school principals. The Arkansas Department of Education (ADE) and the Arkansas Leadership Academy jointly determine the criteria for selection of candidates, review and modify the areas of performance, and develop rigorous assessments. The ADE provides financial incentives on a yearly basis to Master Principals serving as full-time principals in Arkansas public schools as well as Master Principals who are selected and agree to serve in a "high need" school. Master Principals are selected through a rigorous application process and receive professional development, support, and networking opportunities with fellow Master Principals throughout their tenure in the program (NASBE report, p.16).

State-Level Policy Development Framework component: Professional Learning

For more information visit: https://arkansasleadershipacademy.org/programs/master-principal/

\section{Leadership development practice:}

The Arkansas Leadership Academy is a nationally recognized, nonprofit organization whose mission is to develop and support leadership capacity that fosters equity and excellence in education. Working with 51-partners across the state, the academy embraces and models a collaborative learning and work culture to facilitate the development of high-performing individuals and organizations (NASBE report, p. 25).

\section{State-Level Policy Development Framework component: Partnership}

For more information visit: https://arkansasleadershipacademy.org/programs/school-support/

\section{Leadership development practice:}

The Arkansas Department of Education (ADE) will pay $\$ 9,000$ annually for five-years to Master Principals serving full-time in Arkansas public schools; and $\$ 25,000$ annually for five-years to Master Principals who are selected and agree to serve in a "high need" school.

State-Level Policy Development Framework component: Recruitment

For more information visit: $h t t p: / / w w w . a r k l e g . s t a t e . a r . u s / e d u c a t i o n / K 12 /$

BudgetAndFunding/2015-17\%20Silver\%20Manual--Dept\%20of\%20Ed\%20-\%20Public\%20School\%20 Fund.pdf 


\section{California}

Schools: 1,843

Districts: 178

\section{School Districts by Locale}

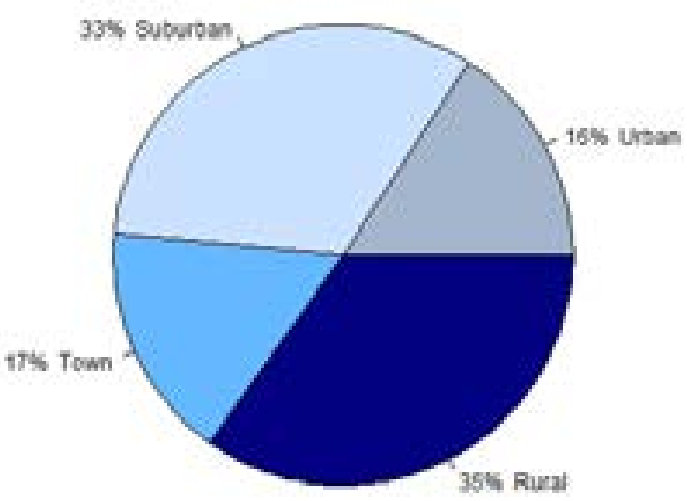

Introduction

\section{How to Use This Document}

Interactive Map

State Profiles

Methods

About Consortium for Policy Research in Education (CPRE)

About National Association of State Boards of Education
In the state of California, the standard setting authority resides with the state board of education. The school leadership standards as of October 2015 are the California Professional Standards for Educational Leaders.

\section{Leadership development practice:}

In February 2014, the California Commission on Teacher Credentialing adopted standards for administrator induction programs called Clear Induction Credential Program Standards. California's Administrator Induction is an individualized, job-embedded, two-year program, initiation of coaching within 120 days of starting an initial administrative position. Professional learning may be offered to candidates through formal and informal partnerships and integrates school and/or district goals. For example, the Commission, in collaboration with the Department of Education, WestEd, and practitioners from the field developed a website that offers information, training ideas, and resources for each of the clear induction standards. The Clear Credential Preparation process is a part of the larger The Learning to Lead System California developed to support school leaders throughout their career continuum.

\section{State-Level Policy Development Framework component: Preparation}

For more information visit: http://www.ctc.ca.gov/educator-prep/ASC.html

\section{Leadership development practice:}

California's DataQuest is a dynamic system that provides reports about California's schools and districts based on school performance indicators, student and staff demographics, test results, and expulsion, suspension, and truancy rates. Data are presented so that users can easily compare schools, districts, and counties (NASBE report, p. 23).

\section{State-Level Policy Development Framework component: Data}

For more information visit: $\underline{h t t p: / / d q . c d e . c a . g o v / d a t a q u e s t / d a t a q u e s t . a s p ~}$

\section{Leadership development practice:}

The Center for Public Education (CPE) has developed data-driven decision-making tools to identify and prioritize areas that most need attention. The tools use a decision-making process that CPE developed in partnership with California School Board Associations.

\section{State-Level Policy Development Framework component: Data}

For more information visit: http://www.data-first.org/leading-the-change/?utm source=Updates+from+the+Center\&utm campaign=1b62703b76-CPE e alert $821 \quad 15821 \quad 2015 \&$ utm medium=email\&utm term=0 4243f7492c$1 \mathrm{~b} 62703 \mathrm{~b} 76-357614225$

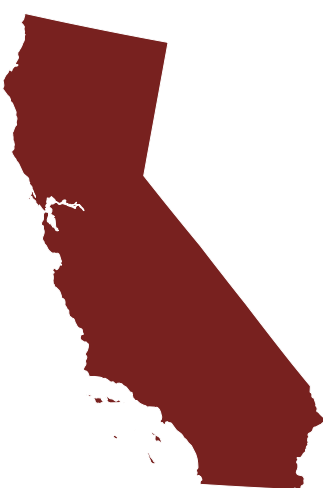

13 | CONSORTIUM FOR POLICY RESEARCH IN EDUCATION | NATIONAL ASSOCIATION OF STATE BOARDS OF EDUCATION 


\section{Colorado}

Schools: 1,843

Districts: 178

School Districts by Locale

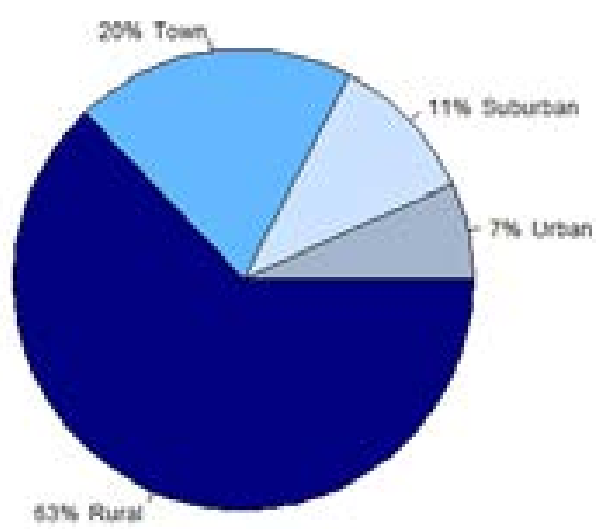

$\underline{\text { Introduction }}$

\section{How to Use This Document}

Interactive Map

\section{State Profiles}

Methods

About Consortium for Policy Research in Education (CPRE)

About National Association of State Boards of Education
In the state of Colorado, the standard setting authority resides with the state board of education. The school leadership standards as of October 2015 are the Colorado Principal Quality Standards.

\section{Leadership development practice:}

The Colorado Department of Education created an extensive district and school data dashboard. The Dashboard presents state data for district and school staff to use to conduct systems analysis and improvement planning. The data tables present principal statistics for each district which includes: average years as a principal, educational experience, and principal turnover.

\section{State-Level Policy Development Framework component: Data}

For more information visit: http://www2.cde.state.co.us/schoolview/dish/dashboard.asp

\section{Leadership development practice:}

The Troop to Principals leadership training program was established two years ago for former US Armed Forces candidates. Candidate selection and induction are directed by a participating school district committee and the School Leaders for America team. After program completion, candidates are issued an initial principal or assistant principal licensure.

\section{State-Level Policy Development Framework component: Recruitment}

For more information visit: http://schoolleadersforamerica.org/troops-to-principals-program/ 


\section{Connecticut}

Schools: 1,300

Districts: 169

\section{School Districts by Locale}

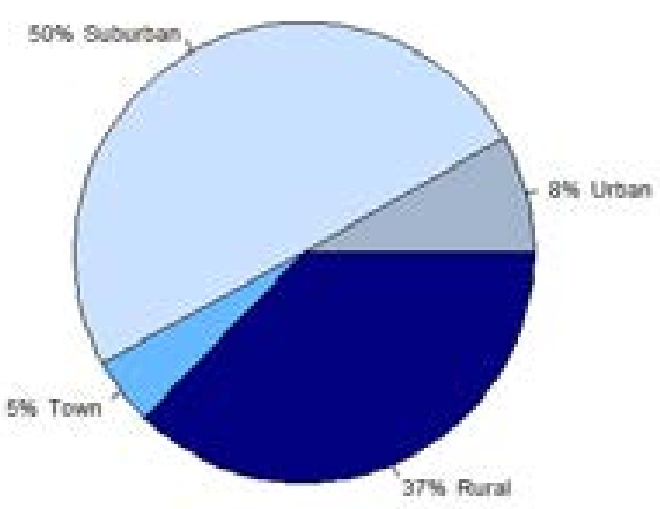

Introduction

\section{Interactive Map}

\section{State Profiles}

Methods

About Consortium for Policy Research in Education (CPRE)

About National Association of State Boards of Education
In the state of Connecticut, the standard setting authority resides with the state board of education. The school leadership standards as of October 2015 are the Connecticut School Leadership Standards.

\section{Leadership development practice:}

The Connecticut State Department of Education in collaboration with Connecticut's institutes of higher education, the Connecticut Association of Boards of Education, and national organizations created LEAD Connecticut. The collaboration supports statewide efforts to recruit, select, prepare, support, and retain educational leaders. Prospective school leaders complete a full-time residency within high-need schools under the mentorship of a current turnaround principal. During their residency, candidates take on specific leadership responsibilities and develop leadership competencies. Participants attend weekly seminars and interact with experts in the field. (NASBE report, p. 12)

State-Level Policy Development Framework component: Partnership

For more information visit: http://leadconnecticut.org/

\section{Leadership development practice:}

Established by the state board of education in 2012, Connecticut's Educator Preparation Advisory Council (EPAC) is a stakeholder group charged with transforming Connecticut's Leader Preparation Program Approval Process. Specifically, EPAC is revising the program approval process and rules to improve and diversify the experience for candidates in school/district leader preparation programs. The council is examining the policies and practices that support aspiring and practicing leaders as they develop school culture and cultural consciousness to lead highpoverty/high-minority schools.

\section{State-Level Policy Development Framework component: Program Approva}

For more information visit: http://www.sde.ct.gov/sde/lib/sde/pdf/talent office/ctequityplan.pdf 


\section{District of Columbia}

Schools: 229

Districts: 1

\section{School Districts by Locale}

Only has one LEA
In the state of DC, the standard setting authority resides with the SBE. The school leadership standards as of October 2015 are $\mathrm{n} / \mathrm{a}$

\section{Leadership development practice:}

The Office of the State Superintendent of Education (OSSE) is the state education agency for the District of Columbia charged with raising the quality of education for all DC residents. OSSE serves as the District's liaison to the U.S. Department of Education and works closely with the District's traditional (LEAs) and public charter schools to achieve its key functions. The OSSE currently provides LEAs with a rubric for evaluating and identifying leaders who can effectively turn around Priority Schools, consistent with its ESEA Waiver.

State-Level Policy Development Framework component: Recruitment

For more information visit: http://osse.dc.gov

\section{$\underline{\text { Introduction }}$}

\section{How to Use This Document}

Interactive Map

\section{State Profiles}

Methods

About Consortium for Policy Research in Education (CPRE)

About National Association of State Boards of Education 


\section{Delaware}

Schools: 225

Districts: 19

\section{School Districts by Locale}

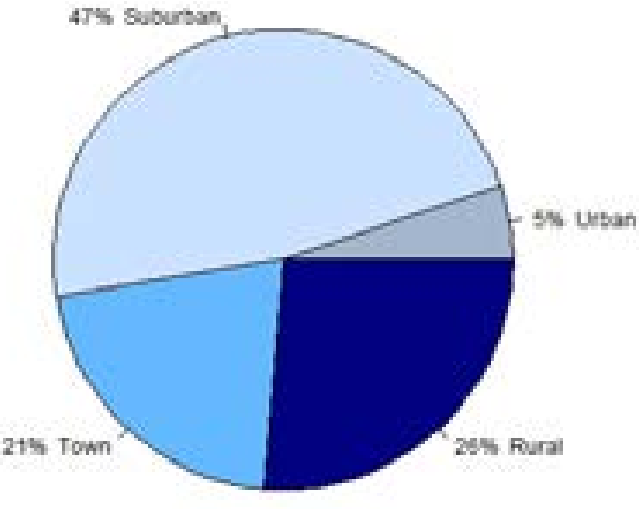

Introduction

\section{How to Use This Document}

Interactive Map

$\underline{\text { State Profiles }}$

Methods

About Consortium for Policy Research in Education (CPRE)

About National Association of State Boards of Education
In the state of Delaware, the standard setting authority resides with the SBE. The school leadership standards as of October 2015 are the Delaware Administrator Standards.

\section{Leadership development practice:}

Delaware invests in the Relay National Principals Academy Fellowship (NPAF) and provides Development Coaches for school-level leaders working in high-need schools. Development Coaches focus on providing support to principals and assistant principals to implement the teacher evaluation system by bolstering leaders' skills in conducting quality observations and coaching teachers. Delaware has formed a partnership with the NPAF to annually train a small cadre of principals of high-need schools to become instructional leaders in their schools.

State-Level Policy Development Framework component: Professional Learning

For more information visit: http://www.rodelfoundationde.org/wp-content/uploads/2016/04/21. Educator-Support-and-Development-Memo.pdf

\section{Leadership development practice:}

The Delaware Department of Education created a community of practice (CoP) specifically focused on the role of the principal supervisor. The CoP is a strategy to improve not only school leaders' effectiveness through evaluation and coaching but also principal retention by creating an environment in which leaders are supported and provided opportunities for continuous growth. This community also serves as venue for principal supervisors to share best practices in how they are coaching and developing school-based leaders. The CoP meets three times a year to discuss principal evaluation topics such as goal-setting, evidence collection, providing feedback to principals.

State-Level Policy Development Framework component: Evaluation

For more information visit: http://www.doe.k12.de.us/cms/lib09/DE01922744/Centricity/Domain/390/ Delaware\%20Excellent\%20Educators\%20for\%20All\%20Plan\%20Body.pdf 


\section{Florida}

Schools: 4,320

Districts: 67

\section{School Districts by Locale}

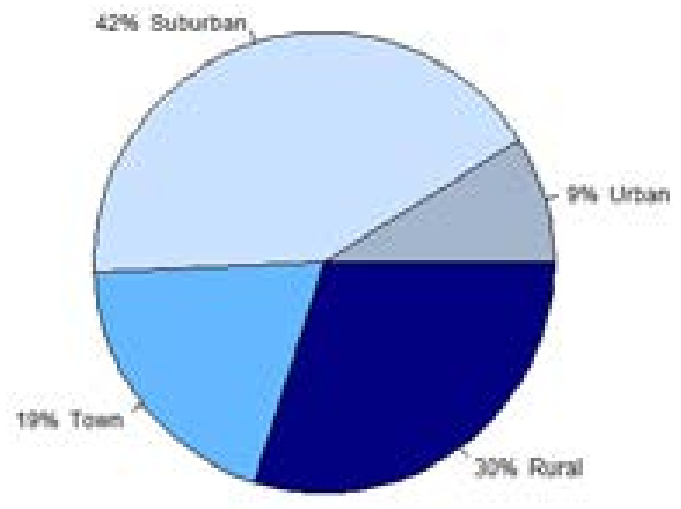

Introduction

\section{How to Use This Document}

Interactive Map

\section{State Profiles}

Methods

About Consortium for Policy Research in Education (CPRE)

About National Association of State Boards of Education
In the state of Florida, the standard setting authority resides with the state board of education. The school leadership standards as of October 2015 are the Florida Principal Leadership Standards.

\section{Leadership development practice:}

The Florida Educational Leadership Examination (FELE) 3.0 was released in January 2014 and is aligned with the 2011 Florida Principal Leadership Standards. The FELE consists of three subtests-Instructional Leadership Operational Leadership and School Leadership. The last subtest, School Leadership, contains a written performance assessment and is scored holistically by trained experts.

\section{State-Level Policy Development Framework component: Certification}

For more information visit: http://www.fldoe.org/accountability/assessments/postsecondary-assessment/ fele/ 
Schools: 2,374

Districts: 182

\section{School Districts by Locale}

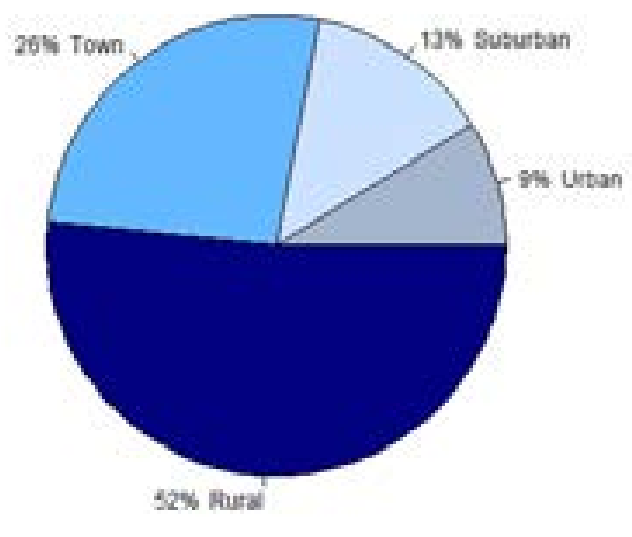

Introduction

\section{How to Use This Document}

Interactive Map

\section{State Profiles}

Methods

About Consortium for Policy Research in Education (CPRE)

About National Association of State Boards of Education

\section{Georgia}

Return to Interactive Map

In the state of Georgia, the standard setting authority resides with the state board of education. The school leadership standards as of October 2015 are the Georgia Educational Leadership (GEL) Standards.

\section{Leadership development practice:}

The Teacher and Leader Effectiveness (TLE) Division of the Georgia Department of Education collaborates with districts, Institutes of Higher Education (IHE), and Regional Education Service Agencies (RESA) to provide guidance in the development and implementation of induction programs that focus on recruiting, retaining, and supporting early career or induction phase principals and their mentors. The GaDOE Principal Induction Guidance provides specific information, induction tools and resources for districts to support. As of September 30, 2014, 100\% of Georgia's, 181 induction phased principals are receiving quality induction support as outlined in the GaDOE induction guidance.

State-Level Policy Development Framework component: Preparation

For more information visit: http://www2.ed.gov/programs/titleiparta/equitable/gaequityplan0601 15.pdf

\section{Leadership development practice:}

In 2013, The Georgia Professional Standards Commission created a four year plan to reform educator preparation programs. The plan is outlined in a comprehensive plan to revise preparation standards, testing requirements, and tiered licensing requirements for school leaders. Once aspect of the plan is to more clearly define the requirements by which educator preparation providers establish and maintain collaborative relationships with P-12 schools that are formalized as partnerships. The partnerships between educator preparation providers and P-12 schools have been refined to be more reciprocal and collaborative.

State-Level Policy Development Framework component: Program Approval

For more information visit: http://www.gapsc.com/GaEducationReform/Downloads/PPEM FAAQs October 2013.pdf 


\section{Guam}

Schools: 38

Districts: 1

\section{School Districts by Locale}

Only has one LEA
In the territory of Guam, the standard setting authority resides with the Guam Education Department. The school leadership standards as of October 2015 are the Guam School Administrator Standards.

\section{Leadership development practice:}

The Guam Department of Education is a single unified school district consisting of grades K-12. They have 26 elementary schools, 8 middle schools, 5 high schools and 1 alternative school serving over 30,000 students. The Guam Education Policy Board established a Bonuses, Rewards and Incentives Program (BR\&l) for the recruitment and retention of teachers and school administrators employed by the Department of Education. School administrators can receive a one-time signing bonus and incentive pay for improving student achievement.

State-Level Policy Development Framework component: Recruitment

For more information visit: https://sites.google.com/a/gdoe.net/gdoe/

\section{Leadership development practice:}

Each summer the Guam Department of Education offers the Principal Leadership Academy. The purpose of the academy is to move the focus of leadership responsibilities away from operational concerns and shift instead to instructional leadership. The recent sessions center on administrators facilitating collaborative conversations with teachers on how to improve student learning.

State-Level Policy Development Framework component: Professional Learning

For more information visit: https://sites.google.com/a/gdoe.net/gdoe/

\section{State Profiles}

Methods

About Consortium for Policy Research in Education (CPRE)

About National Association of State Boards of Education

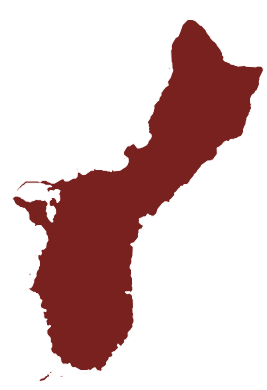


Schools: 289

Districts: 1

\section{School Districts by Locale}

Only has one LEA

\section{Introduction}

\section{How to Use This Document}

Interactive Map

\section{State Profiles}

Methods

About Consortium for Policy Research in Education (CPRE)

About National Association of State Boards of Education

\section{Hawaii}

Return to Interactive Map

In the state of Hawaii, the standard setting authority resides with the state board of education. The school leadership standards as of October 2015 are the Hawaii DOE School Leader Competencies.

\section{Leadership development practice:}

The Hawaii Department of Education created the Leadership Institute with the goal to align the Department's training and development opportunities of school leaders into an pipeline that would also cultivate a culture of leadership among teachers and principals.

\section{State-Level Policy Development Framework component: Professional Learning}

For more information visit: http://www.hawaiipublicschools.org/ConnectWithUs/MediaRoom/PressReleases/ Pages/New-Leadership-Institute-to-Focus-Professional-Development-Efforts.aspx

\section{Leadership development practice:}

The Hawaii Certification Institute for School Leaders (HICISL) is a two-year program and serves as the Department's primary recruitment efforts to support aspiring school leaders. The HICISL program promotes the performance of the participants through coaching, coursework, and residency components. HICISL is administered by the Department's Leadership Institute.

\section{State-Level Policy Development Framework component: Recruitment}

For more information visit: http://www.hawaiipublicschools.org/TeachingAndLearning/EducatorEffectiveness/ ProfessionalDevelopment/Pages/Home.aspx

\section{Leadership development practice:}

In recent years, Hawaii offers the Teacher Leadership Initiative. The initiative was established through a joint effort of the National Education Association, the National Board for Professional Teaching Standards and the Center for Teaching Quality. The goals of this initiative are to identify competencies of teacher leadership, and to help teachers develop those competencies and empower teachers as they engage in relevant leadership experiences. Teacher leaders are guided and supported by coaches, who are teacher leaders themselves. Educators can choose to add 'Teacher Leader' to existing standard or advanced teaching licenses. They first need to have their administrators verify that they have served as teacher leaders for at least four semesters over the past five years.

State-Level Policy Development Framework component: Recruitment

For more information visit: http://www.hawaiipublicschools.org/TeachingAndLearning/ EducatorEffectiveness/ProfessionalDevelopment/Pages/Home.aspx 


\section{Idaho}

Schools: 742

Districts: 115

School Districts by Locale

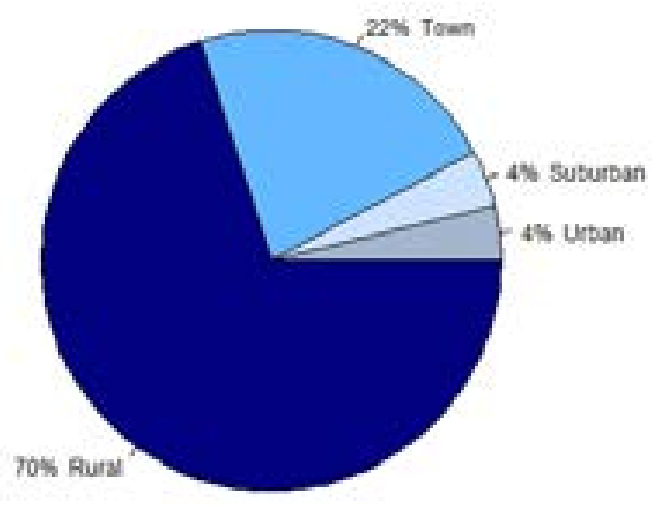

Introduction

How to Use This Document

Interactive Map

\section{State Profiles}

Methods

About Consortium for Policy Research in Education (CPRE)

About National Association of State Boards of Education
In the state of Idaho, the standard setting authority resides with the state board of education. The school leadership standards as of October 2015 are the Idaho Standards for Effective Principals.

\section{Leadership development practice:}

The Idaho Department of Education (IDE) hosts the Idaho Principals Network (IPN) to support the work of school leaders in improving outcomes for all students. IPN is a professional learning community and serves to increase instructional leadership. IDE provides resources such as reesarch, access to experts, and planning to bring prinicpals from across Idaho together to learn and interact around instructional leadership.

State-Level Policy Development Framework component: Professional Learning

For more information visit: http://www.sde.idaho.gov/federal-programs/sis/ipn/files/general/ldahoPrincipals-Network-Application.pdf 


\section{Illinois}

Schools: 4,193

Districts: 863

\section{School Districts by Locale}

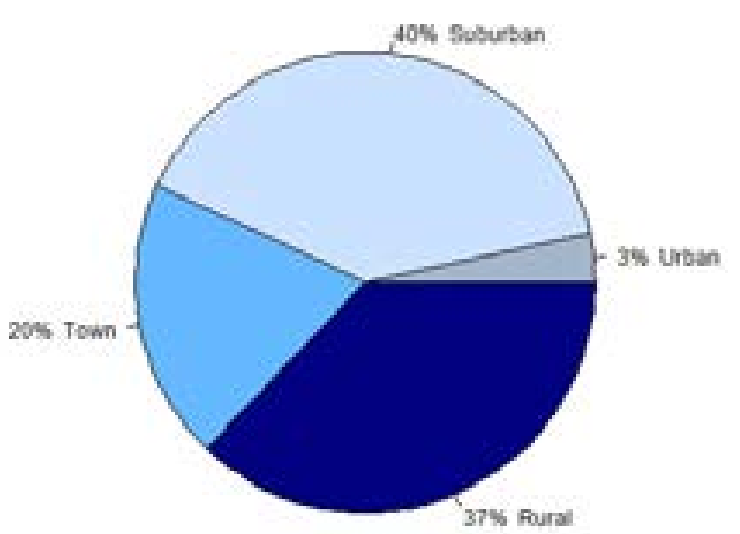

Introduction

\section{How to Use This Document}

Interactive Map

\section{State Profiles}

Methods

About Consortium for Policy Research in Education (CPRE)

About National Association of State Boards of Education
In the state of Illinois, the standard setting authority resides with the state board of education. The school leadership standards as of October 2015 are the Illinois Performance Standards for School Leaders.

\section{Leadership development practice:}

The Illinois State Board of Education (ISBE) facilitated the development of the first Administrators' Academy programs to provide a statewide, regionally based network that offers professional learning opportunities for school administrators. The programs offered through the Administrators' Academy are developed and delivered by the Regional Offices of Education, the Intermediate Service Centers, and other professional development providers. Principals are required to complete one academy per year during their five year license cycle.

State-Level Policy Development Framework component: Professional Learning

For more information visit: http://www.iasaedu.org/domain/30

\section{Leadership development practice:}

In 2010, the Illinois State Legisature sunsetted the general administrative endorsement for school leaders and created a new P-12 principal endorsement. The P-12 endorsement emphasizes the preparation of principals as the instructional leader of a school.

State-Level Policy Development Framework component: Certification

For more information visit: http://www.ilpart.org/new-leadership-requirements.html

\section{Leadership development practice:}

The Center for the Study of Education Policy at Illinois State University presented statewide data report on the supply and demand of principals in Illinois as a result of the 2010 passage of the new P-12 principal endorsement.

State-Level Policy Development Framework component: Data

For more information visit: https://education.illinoisstate.edu/downloads/csep/Principal\%20 Preparation\%20Supply\%20Demand\%20White\%20Paper USE\%20THIS.pdf 


\section{Indiana}

Schools: 1,915

Districts: 295

\section{School Districts by Locale}

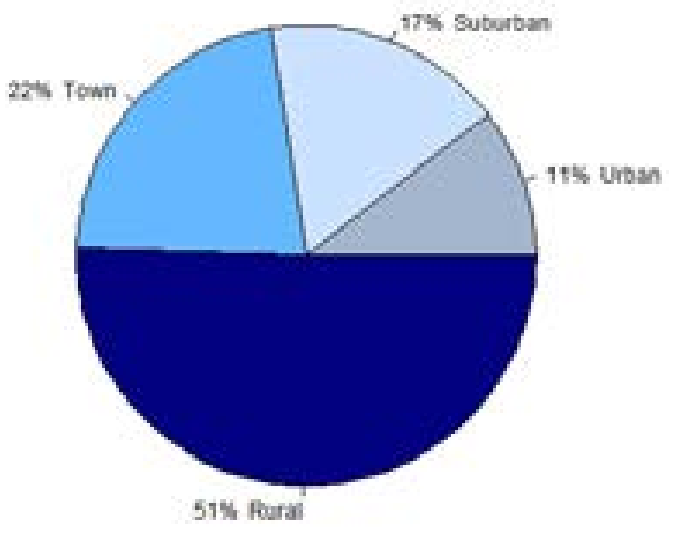

Introduction

How to Use This Document

Interactive Map

\section{State Profiles}

Methods

About Consortium for Policy Research in Education (CPRE)

About National Association of State Boards of Education
In the state of Indiana, the standard setting authority resides with the state board of education. The school leadership standard as of October 2015 is the Indiana Educator Standards for School Leader-Building Level.

\section{Leadership development practice:}

The Woodrow Wilson MBA Fellowship in Education Leadership recruits and prepares outstanding leaders for schools and districts in Indiana. The fifteen-month fellowship program provides aspiring school leaders an integrated business and education curriculum, school-based leadership experience, and individual mentoring. Applicants to the program are nominated by a school leader and attend the partner university in their state. Fellows receive a stipend for tuition and commit to serve their districts in a leadership capacity for three-years (NASBE report, p.18).

State-Level Policy Development Framework component: Preparation

For more information visit: http://woodrow.org/fellowships/ww-ed-mbal

\section{Leadership development practice:}

In 2013, the legislators established a Principal Leadership Institute at Indiana State University. Each year approximately 50 principals enrolled in the institute will learn new leadership, management and communication techniques. The Institute works closely with K-12 districts and partners to support the school leaders in their professional learning.

\section{State-Level Policy Development Framework component: Sponsorship}

For more information visit: http://www.indianapli.org/ipli-about/history-of-ipli/ 


\section{Iowa}

Schools: 1,364

Districts: 346

School Districts by Locale

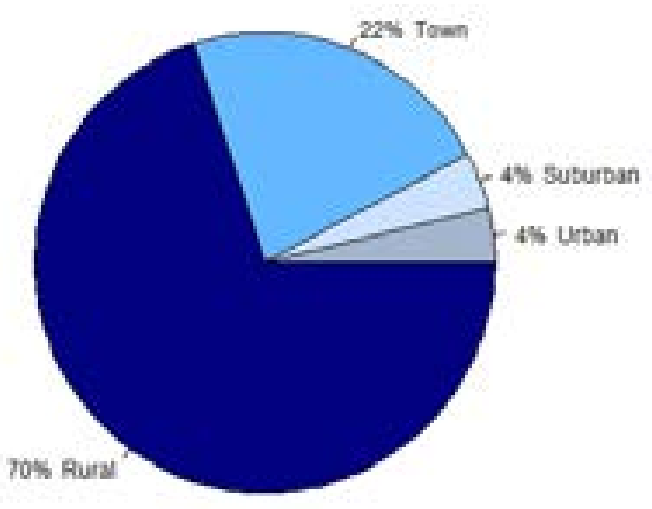

Introduction

\section{How to Use This Document}

Interactive Map

\section{State Profiles}

Methods

About Consortium for Policy Research in Education (CPRE)

About National Association of State Boards of Education
In the state of lowa, the standard setting authority resides with the state board of education. The school leadership standards as of October 2015 are the lowa Standards for School Leaders.

\section{Leadership development practice:}

The mentoring and induction for beginning administrators is mandated by the state, but sponsored by School Administrators of lowa (SAI). This one year program supports the lowa Standards for School Leaders (ISSL) and beginning administrators' professional and personal needs. Qualifying districts and AEAs may receive funding from the state to participate in the program.

\section{State-Level Policy Development Framework component: Sponsorship}

For more information visit: http://www.sai-iowa.org/mentoring-and-induction.cfm

\section{Leadership development practice:}

The Teacher Leadership and Compensation (TLC) Administrator Support Program was created in the last few years to support school leaders as they implemented the TLC system. In collaboration with the NYC Leadership Academy, lowa principals can apply for a year-long professional development program focusing on building their capacity to develop and facilitate distributed leadership in their school by supporting and leveraging teacher leaders as part of the leadership team.

State-Level Policy Development Framework component: Professional Learning

For more information visit: http://www.nycleadershipacademy.org/misc/iowa-tlc-coach-consultant 


\section{Kansas}

Schools: 1,337

Districts: 310

School Districts by Locale

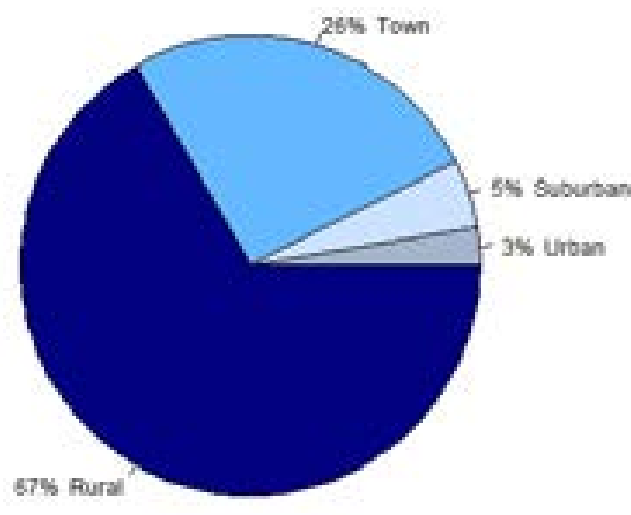

Introduction

How to Use This Document

Interactive Map

$\underline{\text { State Profiles }}$

Methods

About Consortium for Policy Research in Education (CPRE)

About National Association of State Boards of Education
In the state of Kansas, the standard setting authority resides with the state board of education. The school leadership standard as of October 2015 is the Kansas Educator Evaluation Protocol.

\section{Leadership development practice:}

The Kansas Educational Leadership Institute (KELI Institute) is collaborative effort with Kansas State Department of Education, Kansas State University, Kansas School Superintendents Association, United School Administrators of Kansas, and Kansas Association of School Boards to provide induction and mentoring of new superintendents and principals. The institute also offers ongoing professional learning opportunities for district and school leaders and leadership teams.

State-Level Policy Development Framework component: Partnership

For more information visit: https://coe.k-state.edu/annex/keli/ 


\section{Schools: 1,548}

Districts: 173

\section{School Districts by Locale}

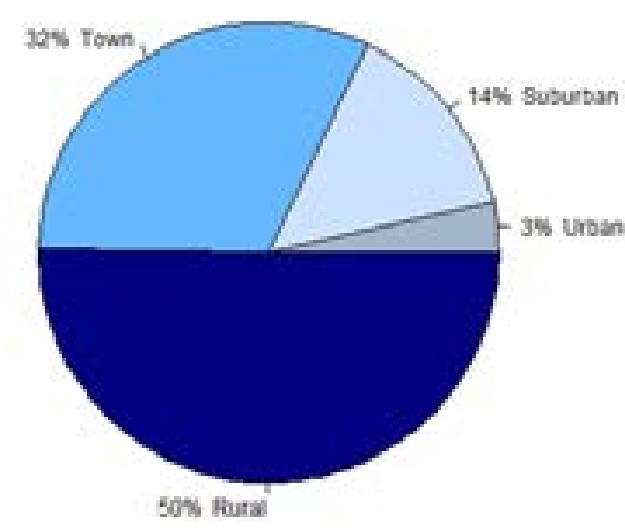

Introduction

\section{How to Use This Document}

Interactive Map

\section{State Profiles}

Methods

About Consortium for Policy Research in Education (CPRE)

About National Association of State Boards of Education

\section{Kentucky}

In the state of Kentucky, the standard setting authority resides with the state board of education. The school leadership standards as of October 2015 are the ISLLC 2008 Standards.

\section{Leadership development practice:}

The Kentucky Department of Education (KDE), the Kentucky Alliance of Black School Educators (KABSE), and Western Kentucky University (WKU) formed a collaborative to identify and prepare minority teachers to become certified administrators in the state. Each partner serves a specific role in delivering the program: KDE provides funding, support staff and consultants for the program. WKU is responsible for curriculum development and delivery. KABSE provides support and mentorship.

\section{State-Level Policy Development Framework component: Partnership}

For more information visit: http://education.ky.gov/teachers/div/Pages/Administrative-Leadership-Institute(ALI).aspX

\section{Leadership development practice:}

Kentucky Leadership Networks have been in place since 2013. The networks are intended to build the capacity of each district and seek to help each school district in the Commonwealth of Kentucky develop a leadership team that guides the professional learning and practice of all administrators, teachers, and staff so that every student succeeds with the new standards.

\section{State-Level Policy Development Framework component: Professional Learning}

For more information visit: http://education.ky.gov/school/Documents/Leadership\%20Network\%20 Information\%20for\%20District\%20Leaders\%202013-16.pdf 


\section{Louisiana}

Schools: 1,384

Districts: 70

\section{School Districts by Locale}

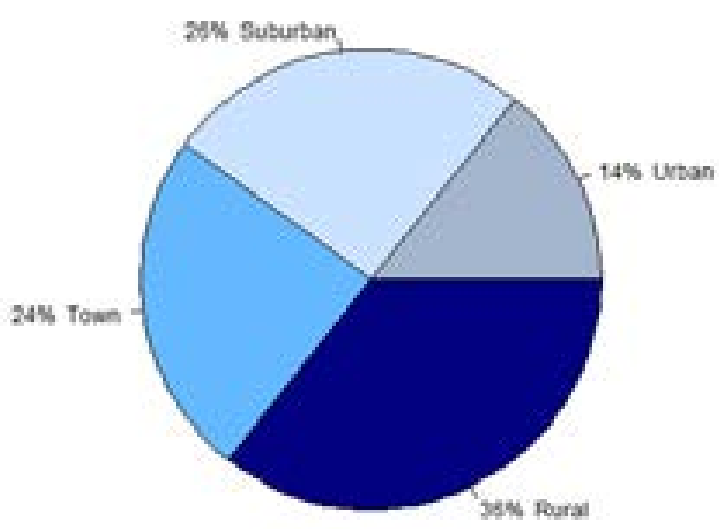

Introduction

\section{How to Use This Document}

Interactive Map

\section{State Profiles}

Methods

About Consortium for Policy Research in Education (CPRE)

About National Association of State Boards of Education
In the state of Lovisiana, the standard setting authority resides with the state board of education. The school leadership standards as of October 2015 are the Lovisiana State Standards for Educational Leaders.

\section{Leadership development practice:}

The Lovisiana Department of Education created a library of Professional Learning Modules designed to allow principals an opportunity to deepen understanding of the instructional leadership cycle. Currently, there are three guidebooks and video modules to support principals as they use Compass, the state's educator evaluation systems as a tool to improve teacher practice and student learning.

State-Level Policy Development Framework component: Professional Learning

For more information visit: https://www.lovisianabelieves.com/academics/compass/professional-learningcenter 


\section{Schools: 616}

Districts: 243

\section{School Districts by Locale}

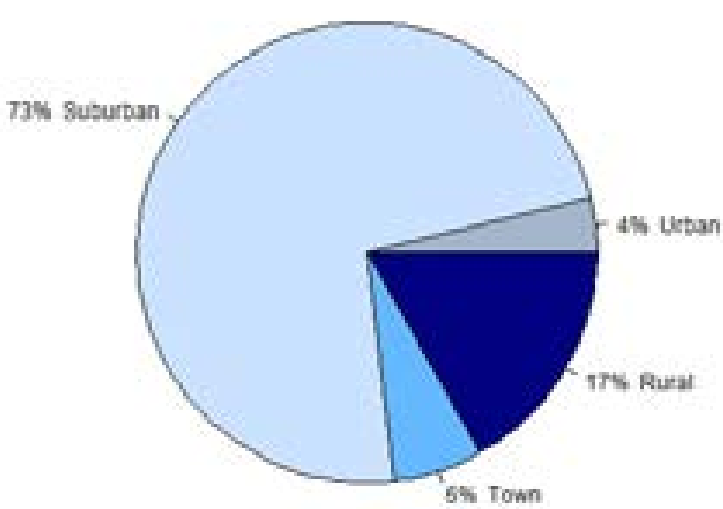

Introduction

\section{How to Use This Document}

Interactive Map

\section{State Profiles}

Methods

About Consortium for Policy Research in Education (CPRE)

About National Association of State Boards of Education

\section{Maine}

\section{Return to Interactive Map}

In the state of Maine, the standard setting authority resides with the Chief State School Officer \& state board of education. The school leadership standards as of October 2015 are the Maine School Building Leadership Standards.

\section{Leadership development practice:}

The state board of education and the Maine Principals' Association secured a NASBE Grant to support the Principal Mentor Program. The program will strengthen both pre-service and in-service principals' instructional leadership capacity.

\section{State-Level Policy Development Framework component: Partnership}

For more information visit: http://mainedoenews.net/2014/04/23/maines-state-board-of-educationreceives-national-grant/

\section{Leadership development practice:}

The Maine Principals' Association working closely with the Maine Department of Education is primarily responsible for creating high quality professional development for all of the educational leaders in Maine. They are the primary professional development resource for all PK-12 schools: from the induction process, on-going mentoring, and meeting their long-term professional learning needs.

State-Level Policy Development Framework component: Partnership

For more information visit: http://www.doe.mass.edu/pal/

and http://www.doe.mass.edu/pal/2015-09LeadershipPrepWebinar.pdf 


\section{Schools: 1,438}

Districts: 24

\section{School Districts by Locale}

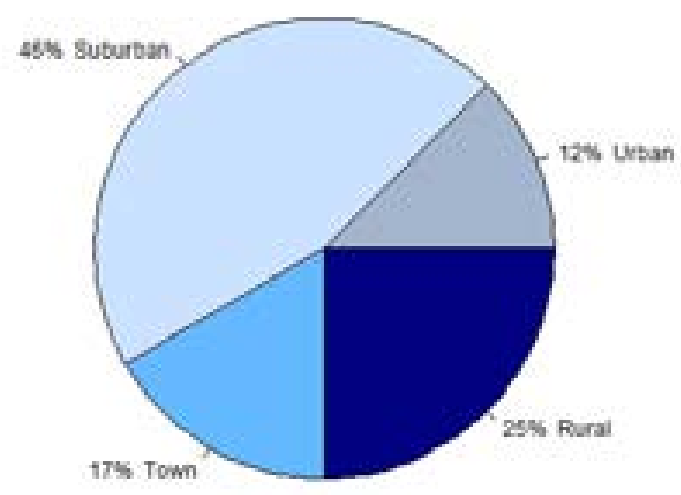

Introduction

How to Use This Document

Interactive Map

\section{State Profiles}

Methods

About Consortium for Policy Research in Education (CPRE)

About National Association of State Boards of Education

\section{Maryland}

\section{Return to Interactive Map}

In the state of Maryland, the standard setting authority resides with the state board of education. The school leadership standard as of October 2015 is the Maryland Instructional Leadership Framework.

\section{Leadership development practice:}

Promising Principals Academy was established by the Maryland State Department of Education to prepare a new cadre of principals. The annual academy prepares promising school leaders nominated by their superintendents to develop leadership skills alongside colleagues from across the state.

\section{State-Level Policy Development Framework component: Recruitment}

For more information visit: http://archives.marylandpublicschools.org/MSDE/programs/tpe/ promisingprincipals/index.htm

\section{Leadership development practice:}

The Maryland Department of Education created the Leadership Learning Series to provide Maryland principals, assistant principals, and potential leaders with the skills, knowledge, and training needed to be effective instructional leaders. The Leadership Learning Series is based on the outcomes and evidences in practice found in the Division's Maryland Instructional Leadership Framework.

State-Level Policy Development Framework component: Professional Learning

For more information visit: http://archives.marylandpublicschools.org/MSDE/divisions/leadership/ leadership dev.html 


\section{Schools: 1,866}

Districts: 240

\section{School Districts by Locale}

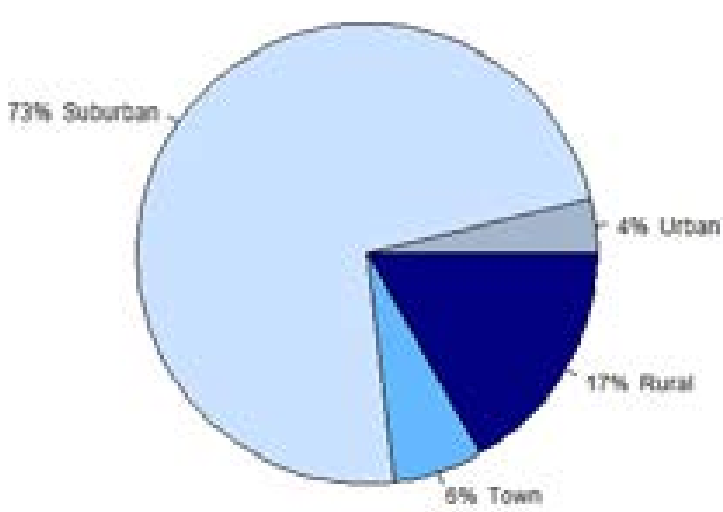

Introduction

\section{How to Use This Document}

Interactive Map

\section{State Profiles}

Methods

About Consortium for Policy Research in Education (CPRE)

About National Association of State Boards of Education

\section{Massachusetts}

In the state of Massachusetts, the standard setting authority resides with the state board of education. The school leadership standards as of October 2015 are the Professional Standards for Administrative Leadership.

\section{Leadership development practice:}

In 2012, The Massachusetts Department of Education revised the standards for all administrator and teacher preparation programs. A year later, all organizations that wanted to run administration preparation programs had to submit to the department their program components for review. The department also created educator preparation program profiles that present data on each of programs, including employment data. Eventually, the profiles will link educator evaluation data to each program.

State-Level Policy Development Framework component: Program Approval

For more information visit: $\underline{\mathrm{htp}: / / \mathrm{w} w w . d o e . m a s s . e d v / e d p r e p / P r o g r a m A p p r o v a l . p d f}$

\section{Leadership development practice:}

The Performance Assessment for Leaders (PAL) is currently required for initial principal licensure in Massachusetts. The PAL assessment is designed to provide clear evidence of an aspiring leaders' preparedness for initial schoo leadership work. The assessment requires the candidates to collect and analyze quantitative and qualitative data in order to complete up to four tasks. The data collected for the task focus on collecting and presenting evidence related to student performance, school culture, and developing a set of goals, objectives, and action strategies related to a school-level issue.

\section{State-Level Policy Development Framework component: Licensure}

For more information visit: http://ma-pal.com/what-is-pal/overview/ and http://www.doe.mass.edu/pal/201509LeadershipPrepWebinar.pdf 
Schools: 3,496

Districts: 548

\section{School Districts by Locale}

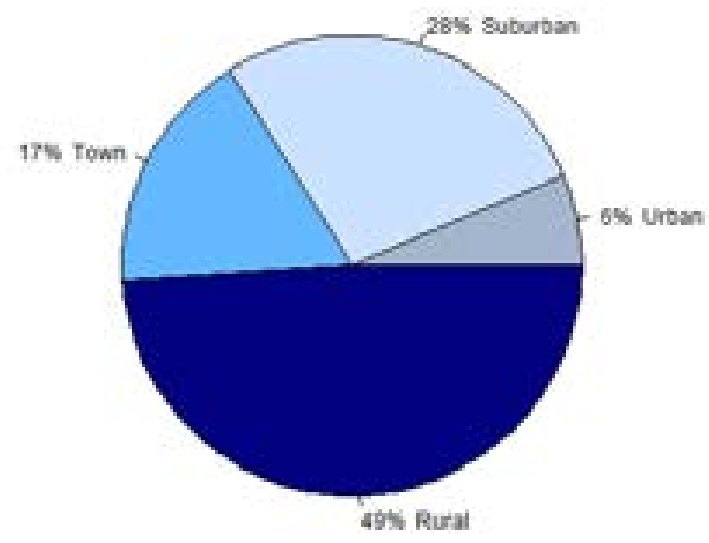

Introduction

How to Use This Document

Interactive Map

\section{$\underline{\text { State Profiles }}$}

Methods

About Consortium for Policy Research in Education (CPRE)

About National Association of State Boards of Education

\section{Michigan}

In the state of Michigan, the standard setting authority resides with the state board of education. The school leadership standards as of October 2015 are the Michigan Standards for the Preparation of School Principals.

\section{Leadership development practice:}

The State of Michigan began improvements to their school administrator programs several years ago. Their efforts include creating and mandating school administrator certification for building-level and central office-level school administrators. The state also developed and streamlined a process to revise school administrator preparation standards to the ELCC Standards 2013

\section{State-Level Policy Development Framework component: Licensure}

For more information visit: www.michigan.gov/documents/mde/SBE item-Adopted Admin-Central Ofc317-09 $2732247 . \mathrm{doc}$

Please note: This document downloads to your computer upon clicking URL. If this does not work, simply copy and paste URL.

\section{Leadership development practice:}

The Center for Public Education (CPE) has developed data-driven decision-making tools to identify and prioritize areas that most need attention. The tools use a decision-making process that CPE developed in partnership with Michigan School Board Association.

\section{State-Level Policy Development Framework component: Data}

For more information visit: http://www. data-first.org/leading-the-change/?utmsource=Updates+from +the+Center\&utm campaign $=1$ b62703b76-CPEealert $821 \quad 158212015 \&$ utm medium=email\&utm term $=0 \quad 4243 f 7492 c-1 b 62703 b 76-357614225$ 


\section{Minnesota}

Schools: 2,436

Districts: 332

\section{School Districts by Locale}

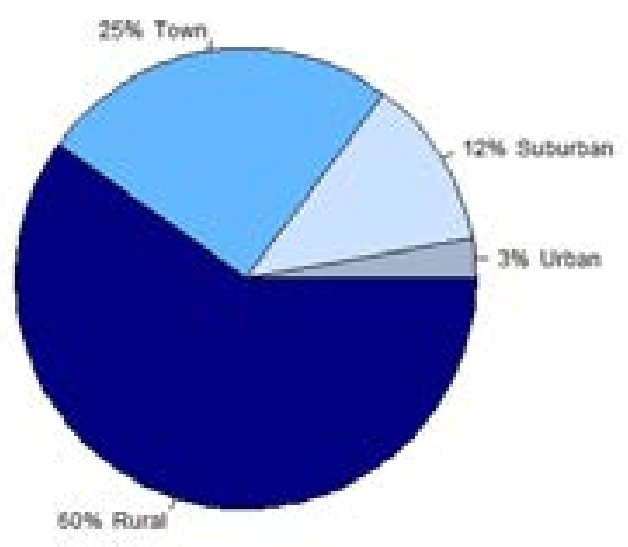

Introduction

\section{How to Use This Document}

Interactive Map

\section{State Profiles}

Methods

About Consortium for Policy Research in Education (CPRE)

About National Association of State Boards of Education
In the state of Minnesota, the standard setting authority resides with the Chief State School Officer. The school leadership standards as of October 2015 are the Core Leadership Competencies for all Minnesota Administrative Licenses.

\section{Leadership development practice:}

The Minnesota Department of Education works with the Regional Centers of Excellence (RCEs) to provide a statewide system of regional support that includes professional learning and support for leadership teams in their region. The six service cooperatives serve as fiscal agents to host the RCEs, each of which has a full-time center director and other staff hired regionally.

State-Level Policy Development Framework component: Partnership

For more information visit: http://education.state.mn.us/MDE/dse/rc/ 
Schools: 1,067

Districts: 154

School Districts by Locale

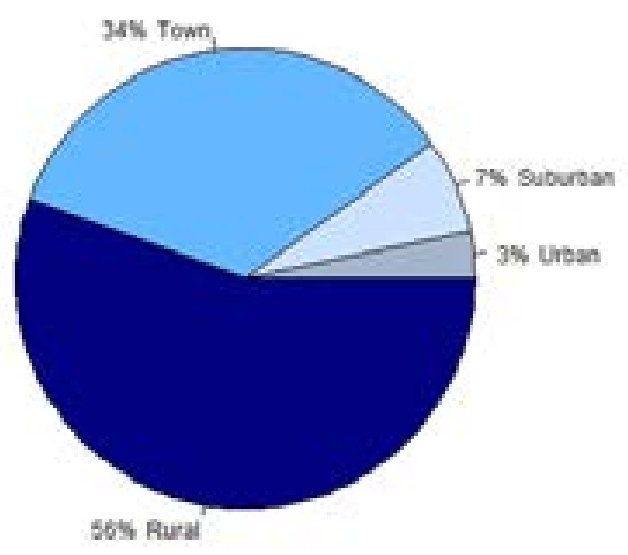

Introduction

\section{How to Use This Document}

Interactive Map

\section{$\underline{\text { State Profiles }}$}

Methods

About Consortium for Policy Research in Education (CPRE)

About National Association of State Boards of Education

\section{Mississippi}

In the state of Mississippi, the standard setting authority resides with the state board of education. The school leadership standards as of October 2015 are the Mississippi Standards for School Leaders.

\section{Leadership development practice:}

In 1998, a school leadership task force report, in concert with lobbying efforts of Delta State University and state education officials, contributed to the state legislature's creation of the Mississippi School Administrator Sabbatical Program. The sabbatical program serves as the state's major recruitment initiative. School districts may grant qualified teachers a one-year leave of absence to participate in an approved full-time administrator preparation program. Participants receive their regular salary and benefits in exchange for a five-year commitment to serve as administrators in their sponsoring school districts. The Mississippi legislature approved the educational administration programs at six universities for participation in the sabbatical leave program..

State-Level Policy Development Framework component: Recruitment

For more information visit: http://law.justia.com/codes/mississippi/2013/title-37/chapter-9/in-general/ section-37-9-77

\section{Leadership development practice:}

Mississippi Department of Education uses Teacher Incentive grant funds to offer an intensive Principals' Academy. The Principals' Academy focuses on leadership development training with best practices for administrators.

State-Level Policy Development Framework component: Professional learning

For more information visit: http://www.mde.k12.ms.us/docs/educator-evaluations/tif-july-2015newsletter 20150928172603 34338.pdf 


\section{Missouri}

Schools: 2,414

Districts: 520

\section{School Districts by Locale}

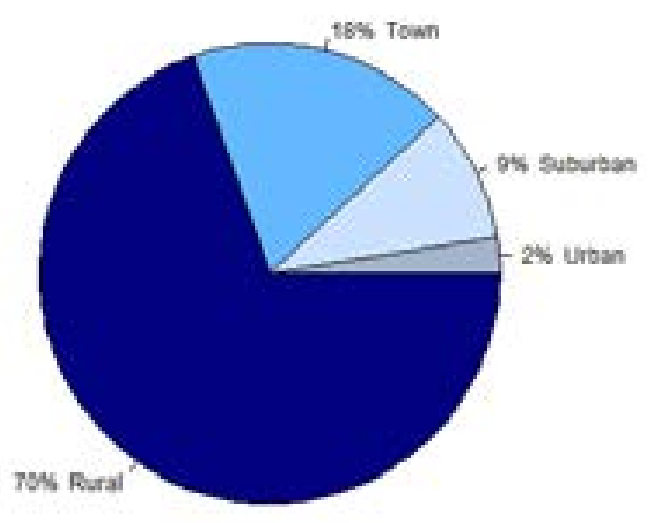

Introduction

\section{How to Use This Document}

Interactive Map

\section{State Profiles}

\section{Methods}

About Consortium for Policy Research in Education (CPRE)

About National Association of State Boards of Education
In the state of Missouri, the standard setting authority resides with the SBE. The school leadership standards as of October 2015 are the Missouri Leader Standards.

\section{Leadership development practice:}

Missouri has recently required a performance-based assessment for principal licensure. The Missouri School Leader Performance Assessment (MOSLPA) assesses candidates' instructional leadership skills. The goals of the performance based system are to develop more effective school leaders, identify strengths and areas for improvement of practice and enhance your instructional leadership practice for the improvement of student learning. The assessment contains three tasks requiring written commentary and submission of required documentation. A video of the candidate conducting a collaborative team experience is also required as one of the tasks. The completed tasks are entered via an online submission system.

State-Level Policy Development Framework component: Licensure

For more information visit: http://mega.ets.org/test-takers/mos/pa/about

\section{Leadership development practice:}

The Missouri Standards for the Preparation of Educators (MOSPE) created an Annual Performance Report for Educator Preparation Programs (APR-EPP) to measure program performance. The Office of Educator Quality, the Office of Data Systems Management, and Missouri's educator preparation programs continue to collaborate in developing this report. The process is to work with the principal programs across the state to support their efforts through a cycle of continuous improvement.

State-Level Policy Development Framework component: Program Approval

For more information visit: https://dese.mo.gov/sites/default/files/APR-Feb2015.pdf

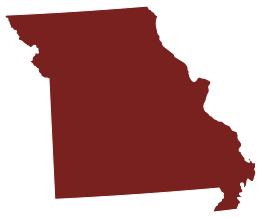




\section{Schools: 824}

Districts: 413

School Districts by Locale

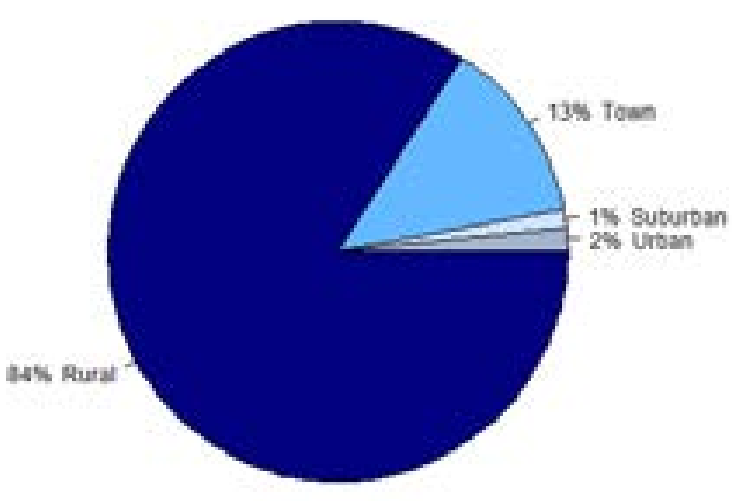

Introduction

\section{How to Use This Document}

Interactive Map

\section{State Profiles}

Methods

About Consortium for Policy Research in Education (CPRE)

About National Association of State Boards of Education

\section{Montana}

\section{Return to Interactive Map}

In the state of Montana, the standard setting authority resides with the State Board of Education. The school leadership standards as of October 2015 are the Montana Professional Educator Preparation Program Standards.

\section{Leadership development practice:}

The School Administrators of Montana (SAM) acts as a liaison with educational agencies such as the Office of Public Instruction, the State Board of Public Education, and the Board of Regents. Annually, SAM hosts summer training sessions and devotes specific training, Leadership Forum to new administrators. The forum is followed by two days of professional development activities that focus on funding, changes in special education law, and state initiatives.

\section{State-Level Policy Development Framework component: Partnership}

For more information visit: http://www.sammt.org/cms/lib03/MT15000278/Centricity/Domain/15/SAM\%20 Team\%20Booklet\%202013.pdf 
Schools: 1,095

Districts: 251

School Districts by Locale

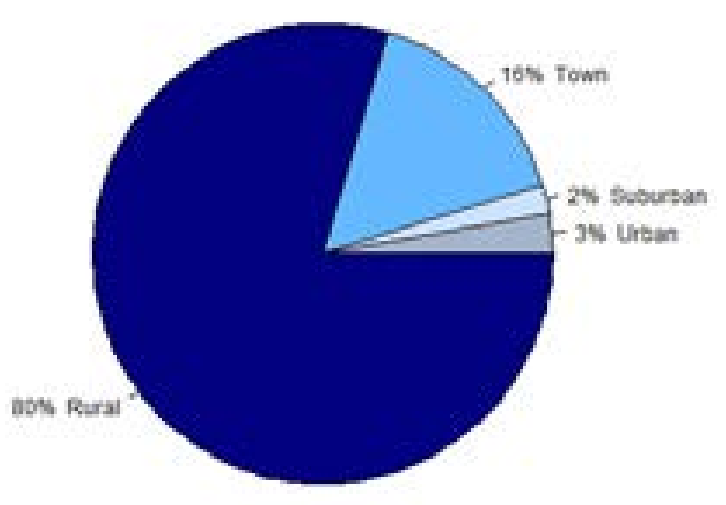

Introduction

\section{How to Use This Document}

Interactive Map

$\underline{\text { State Profiles }}$

Methods

About Consortium for Policy Research in Education (CPRE)

About National Association of State Boards of Education

\section{Nebraska}

Return to Interactive Map

In the state of Nebraska, the standard setting authority resides with the state board of education. The school leadership standards as of October 2015 are the Nebraska Principal Standards.

\section{Leadership development practice:}

In February 2012, the State Board of Education approved the development of models for teacher and principal evaluations based on the Nebraska Teacher and Principal Performance Framework. In the spring of 2013, 17 schools piloted the framework and in 2015-16 school year, the pilot was expanded to any district in the state. The Nebraska Department of Education is working closely with the Educational Service Agencies to support professional learning for school leaders as it relates to the extended pilot program. Currently, there are 17 Educational Service Units (ESUs) across the state supporting all public school districts in Nebraska in the pilot and other professional learning needs for school leaders.

\section{State-Level Policy Development Framework component: Evaluation}

For more information visit: http://www2.ed.gov/programs/titleiparta/equitable/neequityplan0601 15.pdf 


\section{Schools: 665}

Districts: 18

\section{School Districts by Locale}

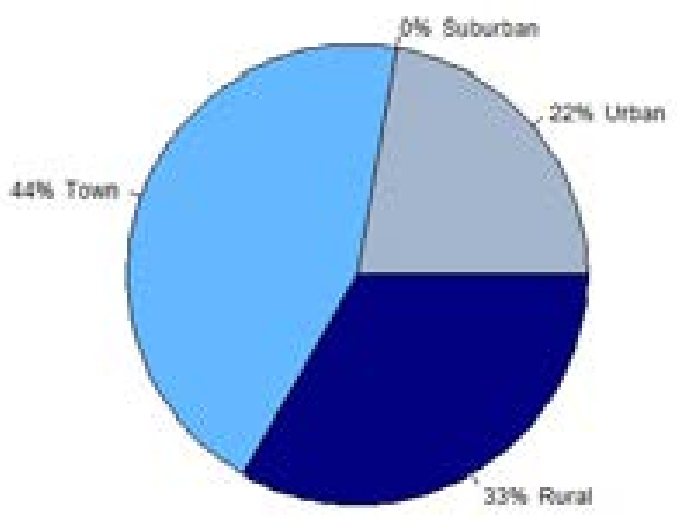

$\underline{\text { Introduction }}$

\section{How to Use This Document}

Interactive Map

\section{State Profiles}

Methods

About Consortium for Policy Research in Education (CPRE)

About National Association of State Boards of Education

\section{Nevada}

In the state of Nevada, the standard setting authority resides with the state board of education. The school leadership standards as of October 2015 are the Nevada Administrator Instructional Leadership Standards \& Indicators.

\section{Leadership development practice:}

The Nevada Department of Education (NDE) chose the Partnership for Leaders in Education based out of the University of Virginia to provide school turnaround leadership for Nevada's school leaders. The Partnership for Leaders in Education is a two-year cohort program designed to educate and support district leaders and principals to focus on improving teaching and learning to improve student achievement. The program includes: a focus on data-driven instruction, effective use of observations and feedback, using feedback tools to assess school readiness and quarterly professional development sessions for the two-year period. School leaders from turnaround schools are invited to participate and apply for the program.

\section{State-Level Policy Development Framework component: Professional Learning}

For more information visit: http://www.doe.nv.gov/uploadedFiles/nde.doe.nv.gov/content/ Schoollmprovement/Underperforming School Support/NDE Leadership Program Overview 2015.pdf 


\section{New Hampshire}

Schools: $\mathbf{4 8 8}$

Districts: 181

School Districts by Locale

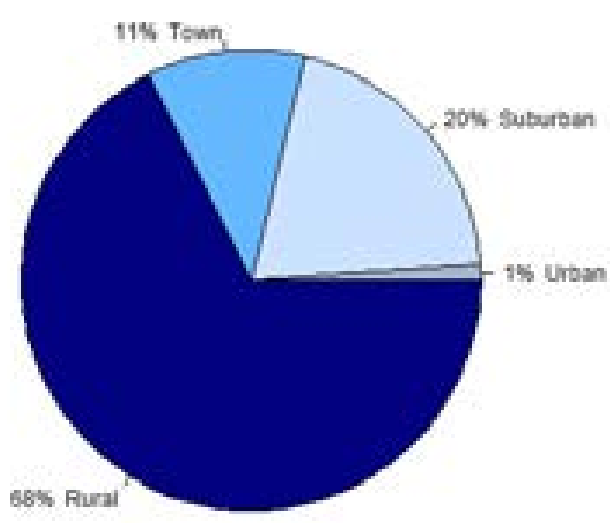

Introduction

\section{How to Use This Document}

Interactive Map

\section{State Profiles}

Methods

About Consortium for Policy Research in Education (CPRE)

About National Association of State Boards of Education
In the state of New Hampshire, the standard setting authority resides with the state board of education. The school leadership standards as of October 2015 are the School Leadership Standards.

\section{Leadership development practice:}

New Hampshire is creating virtual networks for new teachers and principals to collaborate and share their gradelevel, subject-area, or school-leadership challenges and perspectives.

State-Level Policy Development Framework component: Professional Learning

For more information visit: http://www.nheon.org/prof dev/ 
Schools: 2,571

Districts: 594

\section{School Districts by Locale}

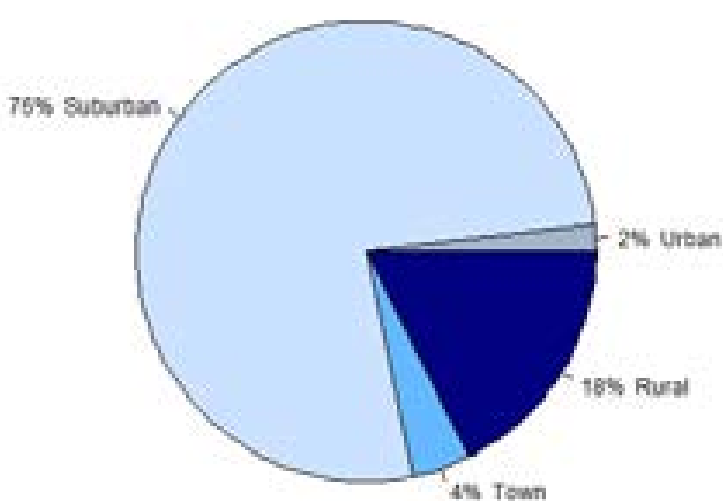

Introduction

\section{How to Use This Document}

Interactive Map

\section{State Profiles}

Methods

About Consortium for Policy Research in Education (CPRE)

About National Association of State Boards of Education

\section{New Jersey}

In the state of New Jersey, the standard setting authority resides with the state board of education. The school leadership standards as of October 2015 are the New Jersey Standards for School Leaders.

\section{Leadership development practice:}

NJ Leaders to Leaders (NJ L2L), a state-approved mentoring and induction program for new school leaders provides trained mentors for new school leaders as they complete the two-year state-requirements for Standard Principal Certification. All school districts with new school administrators are required to register their new administrators with the program. The new school leaders participate in professional learning and support experiences offered by NJ L2L.

State-Level Policy Development Framework component: Partnership

For more information visit: http://www.njl2l.org/

\section{Leadership development practice:}

The New Jersey Leadership Academy is a partnership among the New Jersey Association of School Administrators (NJASA), New Jersey Principals and Supervisors Association (NJPSA), and Foundation for Educational Administration (FEA) with the support of the New Jersey Department of Education offers professional development opportunities for experienced school leaders. The New Jersey Leadership Academy is a year-long, cohort based experience in which practicing school leaders can register for up to five collaborative, professional learning experiences.

State-Level Policy Development Framework component: Partnership

For more information visit: http://www.njpsa.org/nj-leadership-academy/ 


\section{Schools: 885}

Districts: 89

\section{School Districts by Locale}

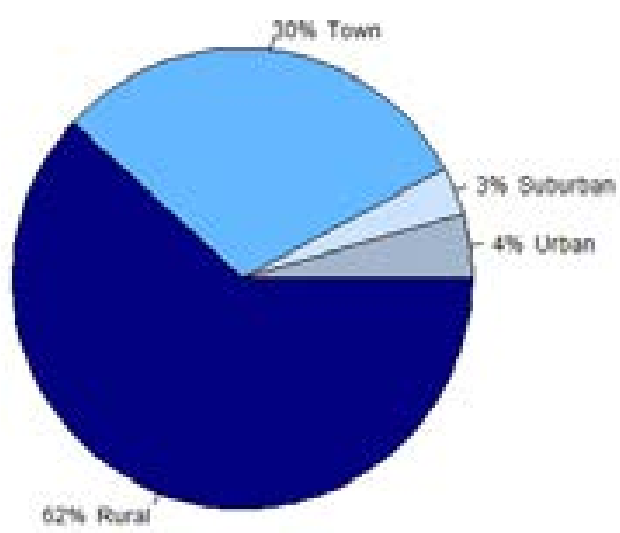

Introduction

\section{How to Use This Document}

Interactive Map

\section{State Profiles}

Methods

About Consortium for Policy Research in Education (CPRE)

About National Association of State Boards of Education

\section{New Mexico}

\section{Return to Interactive Map}

In the state of New Mexico, the standard setting authority resides with the department of education. The school leadership standards as of October 2015 are the New Mexico Principal Leadership Competencies and Indicators.

\section{Leadership development practice:}

The Woodrow Wilson MBA Fellowship in Education Leadership recruits and prepares outstanding leaders for schools and districts in New Mexico. The 15-month fellowship program provides aspiring school leaders an integrated business and education curriculum, school-based leadership experience, and individual mentoring. Applicants to the program are nominated by a school leader and attend the partner university in their state. Fellows receive a stipend for tuition and commit to serve their districts in a leadership capacity for three-years (NASBE report, p.18).

\section{State-Level Policy Development Framework component: Preparation}

For more information visit: http://woodrow.org/fellowships/ww-ed-mba/

\section{Leadership development practice:}

The New Mexico School Leadership Institute (NMSLI) was created by the New Mexico Legislature to establish a system of leadership development for New Mexico schools and districts. Legislation was enacted in 2010 directing NMSLI to create a collaborative infrastructure for strengthening school and district leadership through recruitment, preparation and professional support for school leaders.

State-Level Policy Development Framework component: Sponsorship

For more information visit: http://www.nmsli.org/home.html 


\section{Schools: 4,826}

Districts: 726

\section{School Districts by Locale}

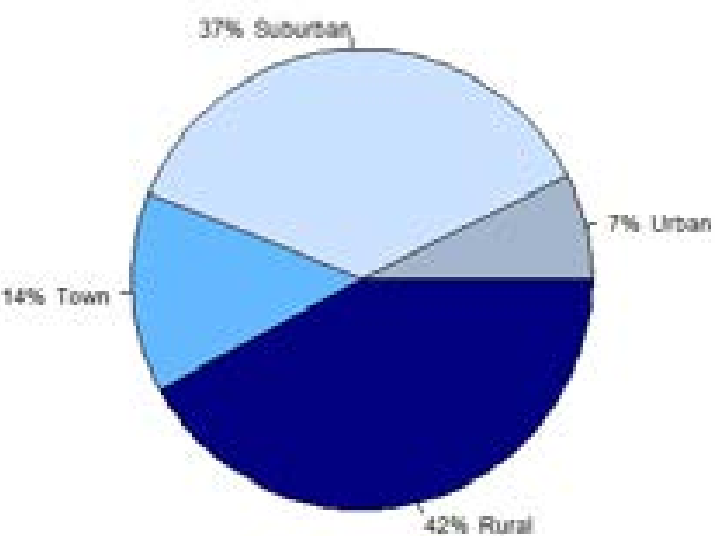

Introduction

How to Use This Document

Interactive Map

\section{State Profiles}

Methods

About Consortium for Policy Research in Education (CPRE)

About National Association of State Boards of Education

\section{New York}

In the state of New York, the standard setting authority resides with the SBE. The school leadership standards as of October 2015 are the New York State Standards for Building Leaders.

\section{Leadership development practice:}

New York created the Principal Mentoring Program for Focus and Priority Schools principals. Principal Mentoring Program is designed to build the instructional capacity of school leaders in high need schools by partnering the principal with a high performing school principal to share and collaborate around "best practices".

\section{State-Level Policy Development Framework component: Preparation}

For more information visit: http://www.p12.nysed.gov/accountability/diagnostic-tool-institute/documents/Men toringPrincipalReadinessAssessmentApplication-Final.doc

Please note: This document downloads to your computer upon clicking URL. If this does not work, simply copy and paste URL.

\section{Leadership development practice:}

For over 10-years, the NYC Leadership Academy has been training aspiring principals using a three phase training model. First, participants are immersed in a six-week summer institute. Second, trainees participate in a six-month school-based residency with a mentor. Third, participants transition into a leadership position in NYC schools. Currently, about one in six of New York City's 1,600 school principals is an NYC Leadership Academy graduate.

\section{State-Level Policy Development Framework component: Partnership}

For more information visit: http://www.nycleadershipacademy.org/programs-and-services/index

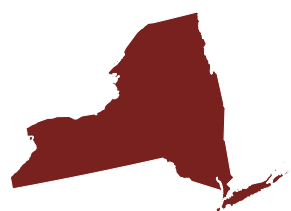


Schools: 2,612

Districts: 115

\section{School Districts by Locale}

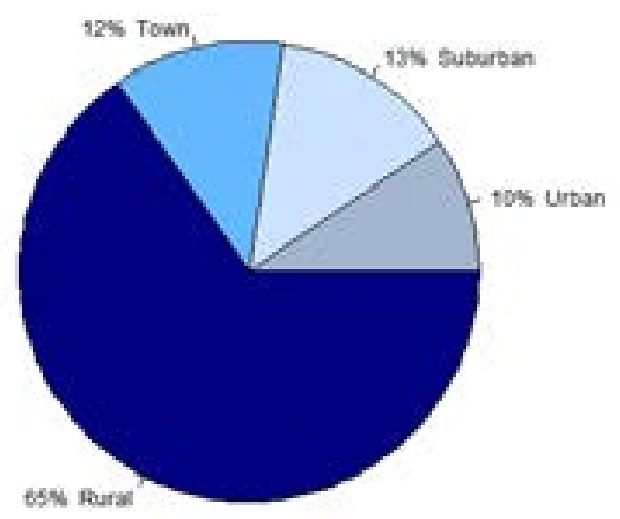

Introduction

\section{How to Use This Document}

Interactive Map

\section{State Profiles}

Methods

About Consortium for Policy Research in Education (CPRE)

About National Association of State Boards of Education

\section{North Carolina}

\section{Return to Interactive Map}

In the state of North Carolina, the standard setting authority resides with the SBE. The school leadership standards as of October 2015 are the North Carolina Standards for School Executives.

\section{Leadership development practice:}

The goal of Northeast Leadership Academy 2.0 (NELA 2.0) is to increase student achievement by preparing and retaining principals and assistant principals to serve as instructional leaders in rural, high-poverty, hard-to-staff, and historically low-performing schools. NELA 2.0 creates an inclusive leadership development program and succession plan for a consortium of 13 high-need school districts throughout the state. The learning elements in NELA 2.0 are anchored in research-based best practices in leadership preparation and are designed to meet the specific leadership needs of rural school leaders serving North Carolina (NASBE report, p. 16).

\section{State-Level Policy Development Framework component: Preparation}

For more information visit: $\underline{\text { http://nela2.wordpress.ncsu.edu/ }}$

\section{Leadership development practice:}

The North Carolina Department of Public Instruction has partnered with local districts and professional organizations to offer READY Principals, a professional learning initiative for school leaders. The program focuses on leveraging strategic and cultural leadership to close the achievement gap by building capacity and instructional leadership practices. Participants engage in a tiered analysis of data and practice to address the performance of their schools, professional learning communities, and individual teachers. Principals collaborate with colleagues and department staff through strong, consistent implementation of the North Carolina Educator Evaluation System (NASBE report, pp. 25 and 26).

State-Level Policy Development Framework component: Partnership

For more information visit: http://ncees.ncdpi.wikispaces.net/READY+Principals

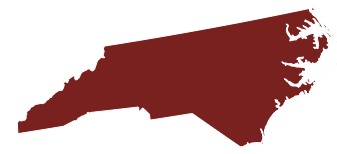




\section{North Dakota}

Schools: 521

Districts: 180

School Districts by Locale

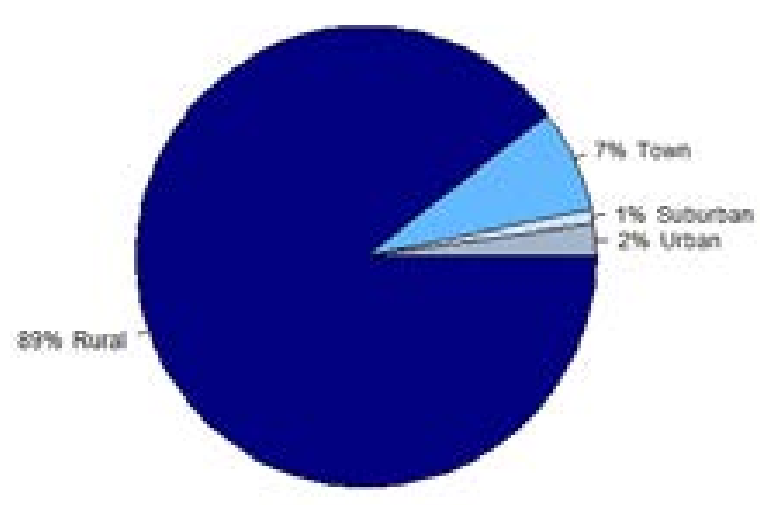

Introduction

\section{How to Use This Document}

Interactive Map

\section{$\underline{\text { State Profiles }}$}

Methods

About Consortium for Policy Research in Education (CPRE)

About National Association of State Boards of Education
In the state of North Dakota, the standard setting authority resides with the Chief State School Officer. The school leadership standards as of October 2015 are the ISLLC Standards.

\section{Leadership development practice:}

North Dakota is one of the only states that requird their districts to identify their principal evaluation frameworks before their teacher evaluation framework. The North Dakota Department of Public Instruction's Teacher \& School Effectiveness team partnered with ND LEAD Center to help ensure all districts had access to professional development opportunities. Grant funding for principal evaluation and professional development support is available from the Teacher \& School Effectiveness Unit. North Dakota Regional Education Associations can apply for the grants to support local districts.

\section{State-Level Policy Development Framework component: Evaluation}

For more information visit: https://www.nd.gov/dpi/Administrators/TSE/FAQ/prineval/ 


\section{Northern Mariana Islands}

Schools: 29

Districts: 1

\section{School Districts by Locale}

Only has one LEA
In the Commonwealth of the Northern Mariana Islands, the standard setting authority resides with the Northern Mariana Islands State Board of Education.

\section{Leadership development practice:}

The Commonwealth of the Northern Marianas Islands Public School System created the SHIFT— Strengthening Highly-Effective Instruction for Tomorrow- project to improve the effectiveness of teachers, principals, and administrative leaders through professional development and training.

State-Level Policy Development Framework component: Professional Learning

For more information visit: http://www.cnmipss.org/
Introduction

How to Use This Document

Interactive Map

State Profiles

Methods

About Consortium for Policy Research in Education (CPRE)

About National Association of State Boards of Education 


\section{Ohio}

Schools: 3,631

Districts: 619

\section{School Districts by Locale}

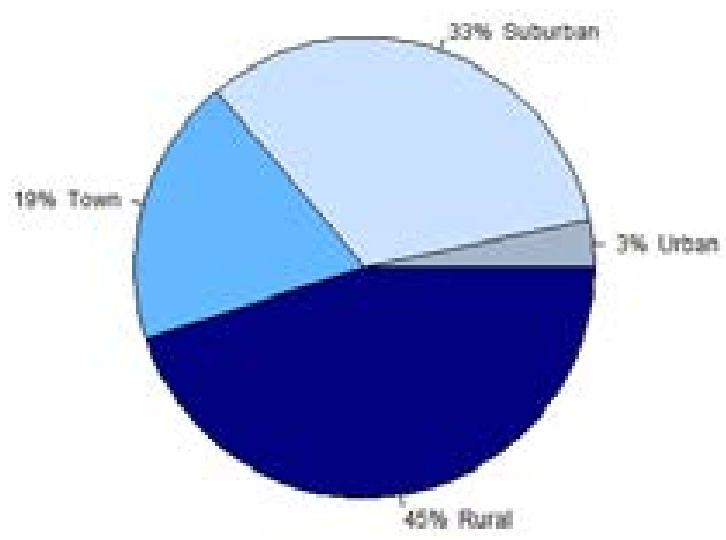

Introduction

How to Use This Document

Interactive Map

$\underline{\text { State Profiles }}$

Methods

About Consortium for Policy Research in Education (CPRE)

About National Association of State Boards of Education
In the state of Ohio, the standard setting authority resides with the state board of education. The school leadership standards as of October 2015 are the Ohio Standards for Principals.

\section{Leadership development practice:}

Bright New Leaders for Ohio is an example of a joint effort among the Ohio Business Roundtable, Ohio Department of Education, and The Ohio State University Fisher College of Business. This program trains future principals to work in Ohio's most challenging schools. Previous experience in education is not required.

\section{State-Level Policy Development Framework component: Partnership}

For more information visit: https://fisher.osu.edu/executive-education/bright-new-leaders-ohio-schools 


\section{Oklahoma}

Schools: 1,796

Districts: 517

\section{School Districts by Locale}

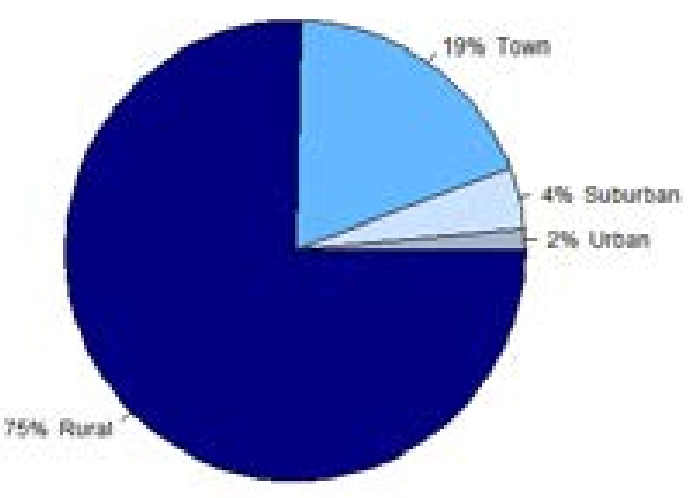

Introduction

\section{How to Use This Document}

Interactive Map

\section{State Profiles}

Methods

About Consortium for Policy Research in Education (CPRE)

About National Association of State Boards of Education
In the state of Oklahoma, the standard setting authority resides with the state board of education. The school leadership standards as of October 2015 are n/a.

\section{Leadership development practice:}

In 2012, the legislature combined two educational agencies, Oklahoma Commission for Teacher Preparation and the Office of Accountability into one organization, The Office of Educational Quality and Accountability (OEQA) to direct and support PK-20 education in Oklahoma. The OEQA oversees educator preparation, and teacher and leaders effectiveness.

\section{State-Level Policy Development Framework component: Program Approval}

For more information visit: https://sites.google.com/a/esucc.org/sda/bucket-teams/leadership-bucket

\section{Leadership development practice:}

The Cooperative Council for Oklahoma School Administration (CCOSA) is an umbrella organization of professional associations from across the state that work together to provide professional learning for school leaders.

State-Level Policy Development Framework component: Partnership

For more information visit: http://www.ccosa.org/index.php?.oassp 
Schools: 1,242

Districts: 180

School Districts by Locale

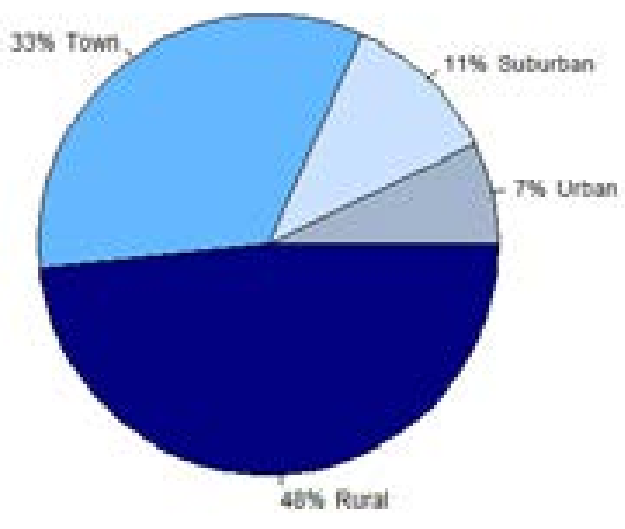

Introduction

How to Use This Document

Interactive Map

$\underline{\text { State Profiles }}$

Methods

About Consortium for Policy Research in Education (CPRE)

About National Association of State Boards of Education

\section{Oregon}

In the state of Oregon, the standard setting authority resides with the State Board of Education. The school leadership standard as of October 2015 is the Oregon Educational Leadership Standard.

\section{Leadership development practice:}

Oregon is one state that is striving to embed equity and cultural competency into school leader preparation coursework. Leading for Learning will help prepare 120 highly efective new school leaders placed by the 2018-19 school year, ready to address the challenges in schools and be better situated to have an immediate impact on student achievement.

\section{State-Level Policy Development Framework component: Preparation}

For more information visit: https://www.cosa.k12.or.us/news/cosa-announces-leading-learning-pilot-project

\section{Leadership development practice:}

The Teacher Standards and Practices Commission has adopted a new design for Oregon Teaching Licenses and recently approved the endorsement for Teacher Leaders.

\section{State-Level Policy Development Framework component: Licensure}

For more information visit: http://www.oregon.gov/TSPC/Pages/index.aspx

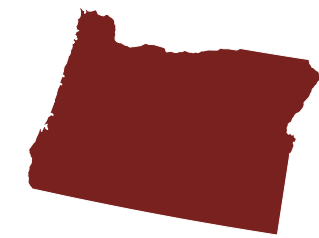


Schools: 3,055

Districts: 500

\section{School Districts by Locale}

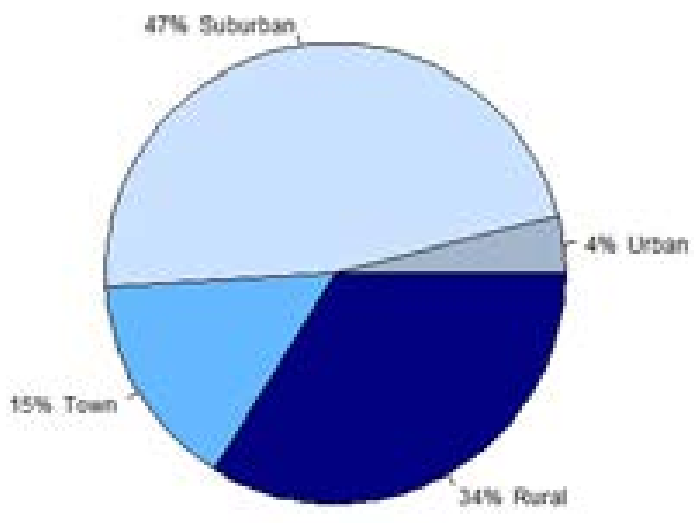

Introduction

How to Use This Document

Interactive Map

State Profiles

Methods

About Consortium for Policy Research in Education (CPRE)

About National Association of State Boards of Education

\section{Pennsylvania}

In the state of Pennsylvania, the standard setting authority resides with the state board of education. The school leadership standards as of October 2015 are the Pennsylvania Leadership Standards.

\section{Leadership development practice:}

The Pennsylvania Inspired Leadership (PIL) Program is a statewide, standards-based continuing professional education program for school and system leaders. The comprehensive, cohort-based program is focused on developing the capacity of leaders to improve student achievement.

State-Level Policy Development Framework component: Professional learning

For more information visit: http://www.education.pa.gov/teachers\%20-\%20administrators/pa\%20 inspired\%20leaders/pages/default.aspx\#tab-1

\section{Leadership development practice:}

The statewide principal evalaution framework, Framework for Leadership, mirrors the statewide teacher evalaution framework.

State-Level Policy Development Framework component: Evaluation

For more information visit: https://static.pdesas.org/content/documents/Principal Rubric.pdf 


\section{Rhode Island}

Schools: 307

Districts: 32

\section{School Districts by Locale}

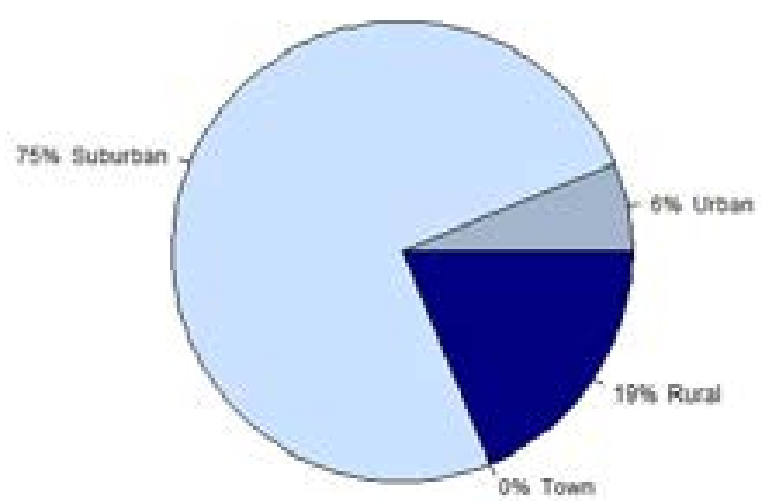

Introduction

How to Use This Document

Interactive Map

\section{State Profiles}

Methods

About Consortium for Policy Research in Education (CPRE)

About National Association of State Boards of Education
In the state of Rhode Island, the standard setting authority resides with the state board of education. The school leadership standards as of October 2015 are the Rhode Island Standards for Educational Leadership.

\section{Leadership development practice:}

Last year, the Rhode Island Department of Education began posting annual reports on educator-preparation programs. These reports - Rhode Island Educator Preparation Indices - provide data on trends in employment retention, and effectiveness of the newly prepared educators such as teachers and school leaders. The reports provide data on the number of program completers, employment placement in Rhode Island, and evaluation data on graduates.

State-Level Policy Development Framework component: Program Approval

For more information visit: http://www.ride.ri.gov/InsideRIDE/Additionallnformation/News/ViewArticle/ tabid/408/Articleld/191/RIDE-posts-first-annual-reports-on-educator-preparation-programs.aspx

\section{Leadership development practice:}

The Principal Residency Network is an alternative route program that has prepared over 130 aspiring school leaders with a focus on educational equity to improving student achievement. The program has operated in the state for the past 15 years and is a residency-based preparation program approved by the Rhode Island Department of Education.

\section{State-Level Policy Development Framework component: Preparation}

For more information visit: http://leadershipandequity.org/becoming-an-equity-oriented-school-leader/ prn/ 


\section{South Carolina}

Schools: 1,244

Districts: 84

\section{School Districts by Locale}

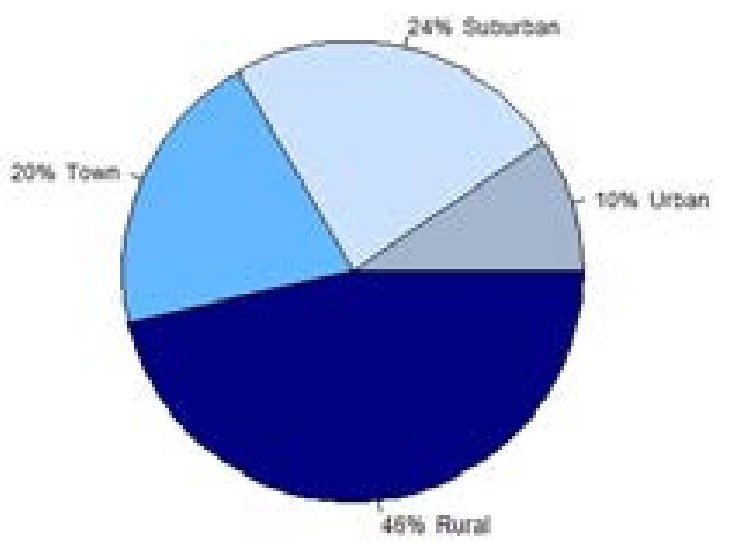

Introduction

\section{How to Use This Document}

Interactive Map

\section{State Profiles}

Methods

About Consortium for Policy Research in Education (CPRE)

About National Association of State Boards of Education
In the state of South Carolina, the standard setting authority resides with the state board of education. The school leadership standards as of October 2015 are the Program for Assisting, Developing, and Evaluating Principal Performance (PADEPP) standards.

\section{Leadership development practice:}

The South Carolina Department of Education (SCDE) has launched a new web-based application, Program for Assisting, Developing, and Evaluating Principal Performance (PADEPP) to collect, analyze, and report data on principal performance and effectiveness of all public school principals in the state.

\section{State-Level Policy Development Framework component: Evaluation}

For more information visit: https://ed.sc.gov/scdoe/assets/File/educators/school-district-admin/PDSDescriptionNovember2011 000.pdf

\section{Leadership development practice:}

The South Carolina Department of Education's School and District Administrator webpage clearly articulates the various stages and certification requirements of a school leader's career and describes the statewide programs that support the individual school leader along their career.

\section{State-Level Policy Development Framework component: Certification}

For more information visit: http://ed.sc.gov/educators/school-and-district-administrators/ 


\section{South Dakota}

Schools: 698

Districts: 152

School Districts by Locale

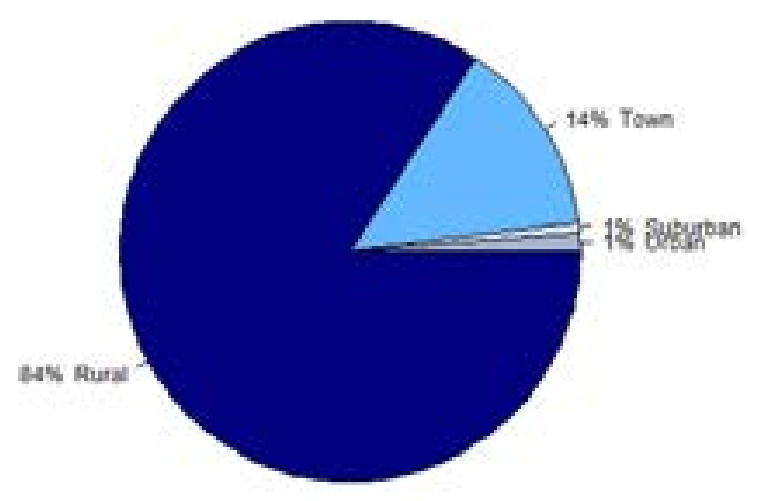

\section{Leadership development practice:}

Educator preparation programs in South Dakota are granted approval by the State Board of Education for a period of 7 years, if the required standards for approval are met. Oglala Lakota College (OLC) will train 25 Indian individuals as school principals in the Lakota Leadership/Management: Educational Administration project. OLC works in partnership with local school districts to assist 14 Indian individuals to complete a Master's Degree in Lakota Leadership Management/Education Administration and achieve state principal endorsement.

State-Level Policy Development Framework component: Program Approval

For more information visit: http://www2.ed.gov/programs/titleiparta/equitable/sdequityplan081315.pdf
In the state of South Dakota, the standard setting authority resides with the state board of education. The school leadership standards as of October 2015 are the South Dakota Principal Standards.

\section{$\underline{\text { Introduction }}$}

\section{How to Use This Document}

Interactive Map

\section{$\underline{\text { State Profiles }}$}

Methods

About Consortium for Policy Research in Education (CPRE)

About National Association of State Boards of Education 
Schools: 1,851

Districts: 146

\section{School Districts by Locale}

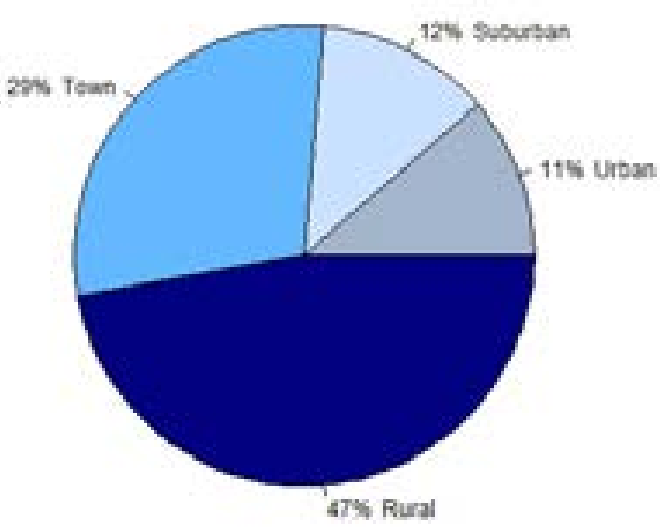

Introduction

\section{How to Use This Document}

Interactive Map

\section{State Profiles}

Methods

About Consortium for Policy Research in Education (CPRE)

About National Association of State Boards of Education

\section{Tennessee}

In the state of Tennessee, the standard setting authority resides with the state board of education. The school leadership standards as of October 2015 are the Tennessee Instructional Leadership Standards.

\section{Leadership development practice:}

The Tennessee Department of Education offers three role-specific induction academies-one for supervisors, one for assistant principals, and one for principals. All beginning leaders must successfully complete an induction academy to advance from a beginning administrator license to a professional administrator license. Participants attend four two-day sessions over two-years. During the academies, principals design and implement a professional learning plan aligned to the Tennessee Instructional Leadership Standards. They also earn credit toward certificate renewal and advancement (NASBE report, p. 24).

\section{State-Level Policy Development Framework component: Preparation}

For more information visit: https://www.tn.gov/education/article/tasl-induction-academies

\section{Leadership development practice:}

The Tennessee Academy for School Leaders (TASL) offered through the Tennessee Department of Education, provides high-quality professional learning opportunities for principals, assistant principals, and instructional supervisors, aligned with the Tennessee Instructional Leadership Standards (TILS).

State-Level Policy Development Framework component: Professional learning

For more information visit: https://www.tn.gov/education/topic/tasl\#sthash.sZXjOGcz.dpuf 


\section{Texas}

Schools: 8,798

Districts: 1,027

School Districts by Locale

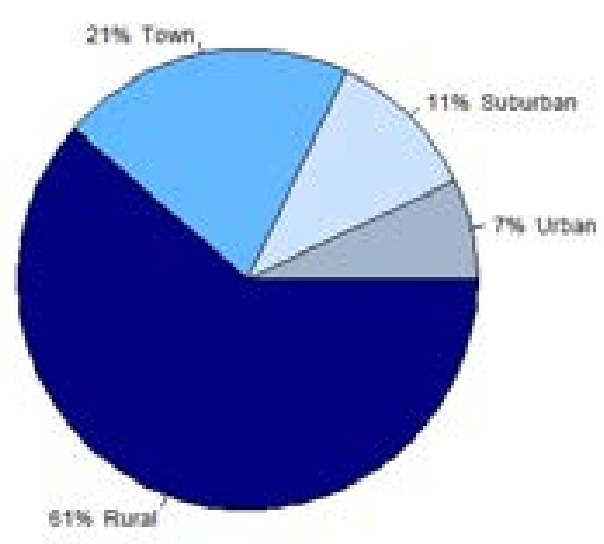

Introduction

\section{How to Use This Document}

Interactive Map

\section{$\underline{\text { State Profiles }}$}

Methods

About Consortium for Policy Research in Education (CPRE)

About National Association of State Boards of Education
In the state of Texas, the standard setting authority resides with the state board of education. The school leadership standards as of October 2015 are the Texas Principal Standards.

\section{Leadership development practice:}

Texas's Public Education Information Management System is one of the largest education databases in the world. It provides a wealth of information about the workings of 1,200 districts and charters, as well as the Texas Education Agency. The information and other data are used to create reports on topics such as student performance, human capital, spending, and implementation of legislation (NASBE report, p. 23).

\section{State-Level Policy Development Framework component: Data}

For more information visit: http://tea.texas.gov/Reports and Data/Data Submission/PEIMS/Public Education Information Management System/

Leadership development practice:

In 1967, the Texas Legislature and the State Board of Education established 20 Education Service Centers throughout the state. These centers provide ongoing professional development to school leaders and other educators. Currently, the state does not offer professional development for school leaders, but they partner with the service centers, professional organizations, and the principal preparation program.

State-Level Policy Development Framework component: Partnership

For more information visit: http://tea.texas.gov/regional services/esc/

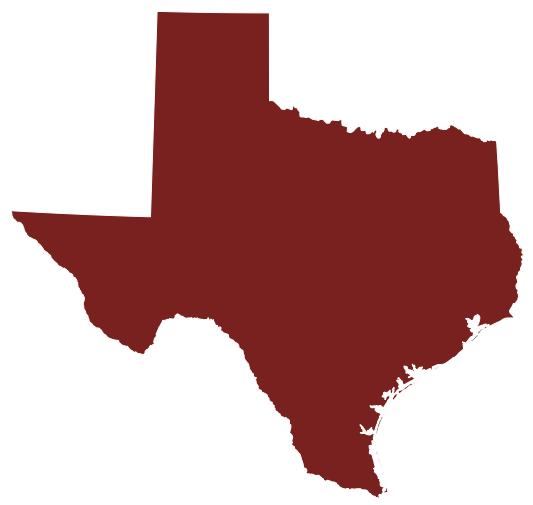




\section{Utah}

Schools: 1,020

Districts: 41

\section{School Districts by Locale}

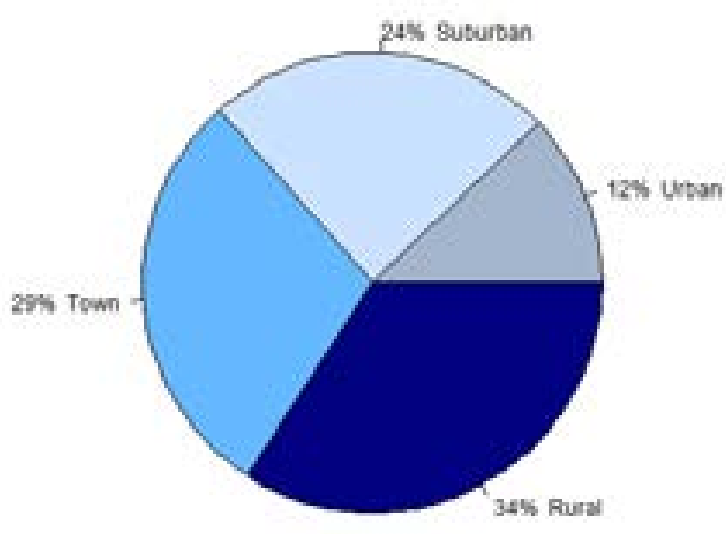

Introduction

\section{How to Use This Document}

Interactive Map

$\underline{\text { State Profiles }}$

Methods

About Consortium for Policy Research in Education (CPRE)

About National Association of State Boards of Education
In the state of Utah, the standard setting authority resides with the state board of education. The school leadership standards as of October 2015 are the Utah Educational Leadership Standards.

\section{Leadership development practice:}

In October 2015, Utah State Legislature passed the School Turnaround and Leadership Development Act. Under the act, the state board will create a School Leadership Development Program aimed at training and supporting principals in school turnaround efforts. School leaders may apply to participate in the School Leadership Development Program if the school leader is nominated by a superintendent.

State-Level Policy Development Framework component: Professional learning

For more information visit: http://www.rules.utah.gov/publicat/bulletin/2015/20151015/39789.htm 
Schools: 316

Districts: 294

School Districts by Locale

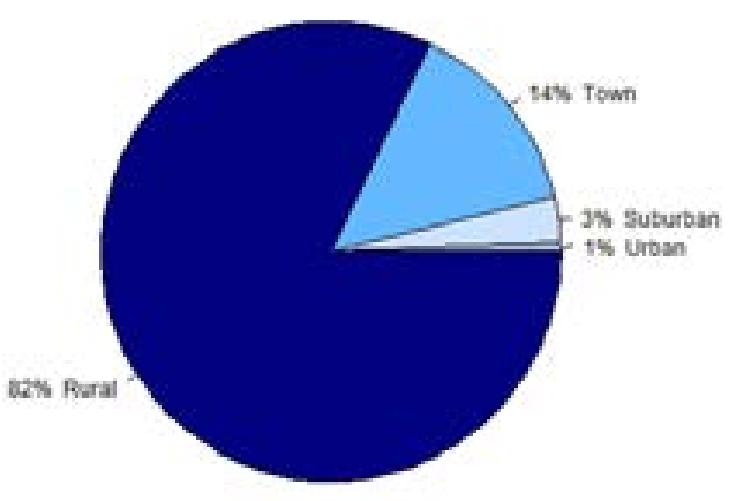

Introduction

How to Use This Document

Interactive Map

State Profiles

Methods

About Consortium for Policy Research in Education (CPRE)

About National Association of State Boards of Education

\section{Vermont}

In the state of Vermont, the standard setting authority resides with the state board of education. The school leadership standards as of October 2015 are the Core Leadership Standards for Vermont Educators.

\section{Leadership development practice:}

The Vermont Department of Education supports Collaborative Learning Groups (CLG), a professional learning community designed to bring together principals, instructional coaches, and curriculum coordinators to work collaboratively around Education Quality Standards.

State-Level Policy Development Framework component: Partnership

For more information visit: https://www.surveymonkey.com/r/VT PLN Application 


\section{Schools: 2,134}

Districts: 134

\section{School Districts by Locale}

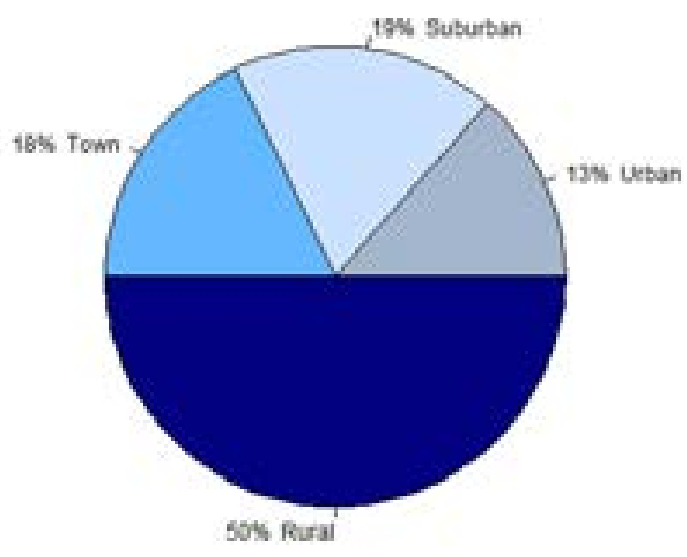

Introduction

\section{How to Use This Document}

Interactive Map

\section{State Profiles}

Methods

About Consortium for Policy Research in Education (CPRE)

About National Association of State Boards of Education

\section{Virginia}

Return to Interactive Map

In the state of Virginia, the standard setting authority resides with the state board of education. The school leadership standards as of October 2015 are the Virginia Performance Standards for School Leaders.

\section{Leadership development practice:}

In 2012, the state updated their leadership agenda and revised criteria for leadership certification. These updates were published in Advancing Virginia's Leadership Agenda Guidance Document: Standards and Indicators for School Leaders and Documentation for the Principal of Distinction (Level II) Administration and Supervision Endorsement. The guide was initially supported by a grant from the Wallace Foundation to support the initiative of "Advancing Virginia's Leadership Agenda." This funding was to strengthen standards and identify indicators for school leaders and provide guidance to school divisions in recommending principals for the Principal of Distinction (Level II) administration and supervision endorsement.

State-Level Policy Development Framework component: Certification

For more information visit: http://doe.virginia.gov/teaching/career resources/leadership/advancing leadership.pdf

\section{Leadership development practice:}

For a principal to earn the endorsement of a Principal of Distinction (Level II) from the State of Virginia, the principal must submit evidence in the form a portfolio that demonstrates that they have moved from proficient level of leadership toward excellence in leadership at the building level. Candidates must complete a 360 assessment of their leadership skills and a community profile of the school in which they work. The completed portfolio is submitted to the superintendent for review and determination of whether the principal met all requirements.

\section{State-Level Policy Development Framework component: Certification}

For more information visit: http://doe.virginia.gov/teaching/career resources/leadership/advancing leadership.pdf 
Schools: 2,398

Districts: 302

School Districts by Locale

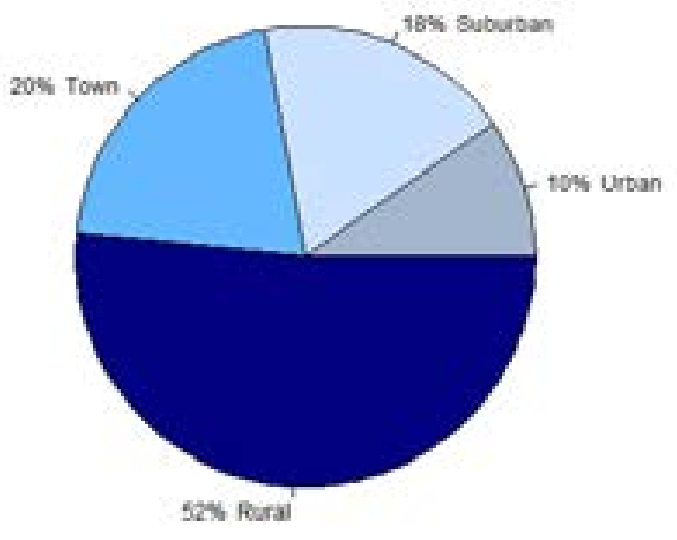

Introduction

\section{How to Use This Document}

Interactive Map

\section{State Profiles}

Methods

About Consortium for Policy Research in Education (CPRE)

About National Association of State Boards of Education

\section{Washington}

In the state of Washington, the standard setting authority resides with the Chief State School Officer. The school leadership standards as of October 2015 are Washington State Standards (based on ISLLC).

\section{Leadership development practice:}

The Washington State-Funded Education Leadership Intern Program provides funds to public school districts for the partial release time of district employees to participate in an administrative intern and mentoring program. The Washington State-Funded Education Leadership Intern Program is managed by the Washington School Principals' Education Foundation (WSPEF) in cooperation with Office of Superintendent of Public Instruction (OSPI).

State-Level Policy Development Framework component: Sponsorship

For more information visit: http://www.awsp.org/professionaldevelopment/principalinterns/interngrant

\section{Leadership development practice:}

The State of Washington Professional Standards Board defines three levels of the career continuum for principals: residency, professional, and career. For each level, the state created benchmarks identified by standards and a timeline to meet each benchmark.

\section{State-Level Policy Development Framework component: Licensure}

For more information visit: http://wcm.awsp.org/awspdocuments/CertTimeLineGraphic.pdf 
Schools: 750

Districts: 55

\section{School Districts by Locale}

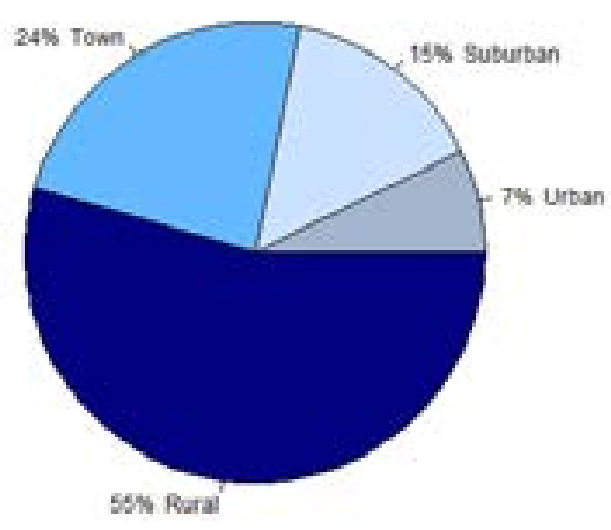

Introduction

\section{How to Use This Document}

Interactive Map

\section{State Profiles}

Methods

About Consortium for Policy Research in Education (CPRE)

About National Association of State Boards of Education

\section{West Virginia}

In the state of West Virginia, the standard setting authority resides with the state board of education. The school leadership standards as of October 2015 are West Virginia Professional Leadership Standards.

\section{Leadership development practice:}

The Building Leadership Capacity in Rural West Virginia project began in 2015 and is a five-year principal leadership development demonstration project funded by the U.S. Department of Education Office of Innovation and Improvement. The School Leadership Program (SLP) assists high-need rural educational agencies (LEAs) in recruiting, training, and supporting principals and assistant principals. The overall goal of the SLP is to increase student achievement by investing in innovative projects that prepare aspiring principals and provide professional development and support to current principals to foster development of leadership skills based on the ISLLC standards (NASBE report, p.16).

State-Level Policy Development Framework component: Partnership

For more information visit: http://edleadership.wix.com/leadership-in-wv\#!project-overview/cihc

\section{Leadership development practice:}

The West Virginia Center for Professional Development (WVCPD) provides the professional development of West Virginia school leaders and professional educators. The WVCPD hosts the Principals' Leadership Academy (PLA) to support new principals and experienced principals. The goal of the academy is to enhance school leaders' ability to improve student achievement.

State-Level Policy Development Framework component: Professional Learning

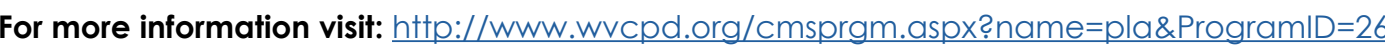




\section{Wisconsin}

Schools: 2,254

Districts: 421

\section{School Districts by Locale}

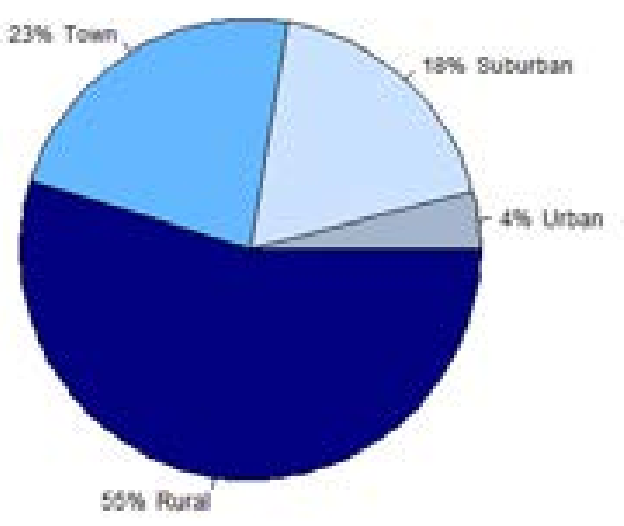

Introduction

How to Use This Document

Interactive Map

\section{State Profiles}

Methods

About Consortium for Policy Research in Education (CPRE)

About National Association of State Boards of Education
In the state of Wisconsin, the standard setting authority resides with the Chief State School Officer. The school leadership standards as of October 2015 are the Wisconsin Educator Standards for Administrators.

\section{Leadership development practice:}

Using statewide educator evaluation results, Wisconsin is disaggregating its principal evaluation data to determine the areas of leadership in which their principals need support. As the state identifies areas of need, they are convening stakeholders and leading the conversation across the state to provide support and outreach to principals in order to strengthen leadership capacity (NASBE report, p. 13).

State-Level Policy Development Framework component: Data

For more information visit: http://dpi.wi.gov/ee

\section{Leadership development practice:}

The Woodrow Wilson MBA Fellowship in Education Leadership recruits and prepares outstanding leaders for schools and districts in Wisconsin. The 15-month fellowship program provides aspiring school leaders an integrated business and education curriculum, school-based leadership experience, and individual mentoring. Applicants to the program are nominated by a school leader and attend the partner university in their state. Fellows receive a stipend for tuition and commit to serve their districts in a leadership capacity for three-years (NASBE report, p.18).

\section{State-Level Policy Development Framework component: Preparation}

For more information visit: http://woodrow.org/fellowships/ww-ed-mba/

\section{Leadership development practice:}

Wisconsin Educator Effectiveness (WIEE) System identifies the unique strengths and weaknesses of every school leader. The System validates every context, role, environment, and results in meaningful, individualized, actionable feedback. Wisconsin has worked hard to create an EE System aligned to research and best practice by providing feedback which results in educator growth and, ultimately, improved student outcomes (NASBE report, p. 26).

State-Level Policy Development Framework component: Evaluation

For more information visit: http://dpi.wi.gov/ee/principal/resources/forms

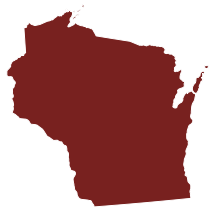


Schools: 367

Districts: 48

\section{School Districts by Locale}

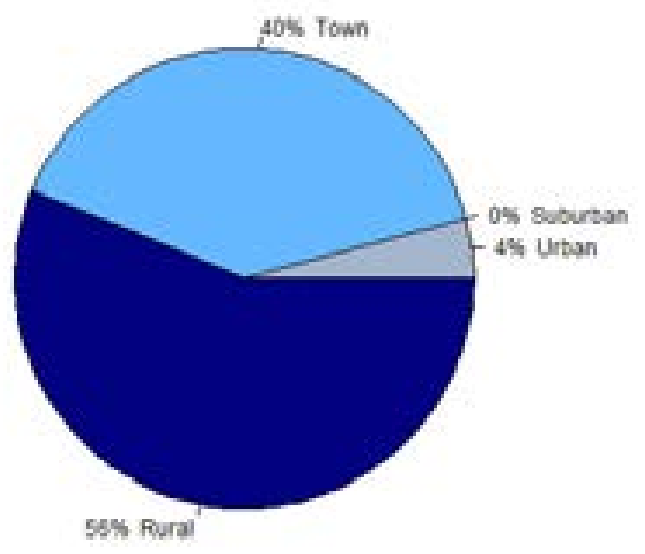

Introduction

\section{How to Use This Document}

Interactive Map

\section{State Profiles}

Methods

About Consortium for Policy Research in Education (CPRE)

About National Association of State Boards of Education

\section{Wyoming}

\section{Return to Interactive Map}

In the state of Wyoming, the standard setting authority resides with the state board of education. The school leadership standards as of October 2015 have not been identified by the state.

\section{Leadership development practice:}

Wyoming Department of Education (WDE) with the support of the State Board of Education developed a partnership with the University of Wyoming's Center for Educational Leadership to provide professional learning and support for selected school principals. The first Wyoming Principal's Leadership Academy will provide support for a cohort of 25 school leaders. The focus of the academy will be action research and approximately $25 \%$ of the content and time in the academy will be reserved for Wyoming related issues which will include presentations from the WDE and Wyoming administrators.

\section{State-Level Policy Development Framework component: Partnership}

For more information visit: http://www.wasa-wy.org/resources/WyCEL-TIE-WPLA.pdf 


\section{Methods}

Researchers conducted a qualitative inquiry to examine existing state policies that focus on school leadership development. Researchers developed a structured interview protocol to collect data from each state about their state policies and programs in the following areas: recruitment, preparation, licensure, accreditation of school leadership preparation programs, support and retention of school principals, evaluation, and state monitoring or data collection effort of the leadership development process for school leaders.

State board members and/or staff members from state education agencies that oversee school leadership development participated in phone interviews conducted by researchers. More than 50 interviews were conducted, in a few cases, fewer than five; state education agencies provided written responses to protocol questions instead of participating in a phone interview. The State-Level Policy Development Framework informed the creation of the coding scheme. The deductively created codes reflect the components of the framework. To supplement interview data, researchers also conducted document analysis of state education agency policies and programs to supplement or provide more detail of policy and programs. Final analysis was guided by identifying leadership development policies and programs that exist across states as compared to the framework.

Researchers used administrative data to construct pie charts of school districts by locale type for each state in the union, plus the District of Columbia (DC), Guam, and the Northern Mariana Islands. This addendum describes data sources and methods used to create these figures. Data from the National Center for Education Statistics (NCES) Common Core of Data (CCD) were used to generate the school district locale pie charts. The 2014-15 CCD Local Education Agency (LEA) file was downloaded (available at http://nces.ed.gov/ccd/pubagency. asp as of $01 / 5 / 2016$ ), and this file contained a census of all school districts in the nation. Because the initial release of the file contains only basic information about each district, the 2013-14 LEA CCD file was downloaded to incorporate urban-centric locale codes. The files were merged in order to acquire the most current list of school districts 
alongside the most recently published locale codes. Since the 201415 file included new districts not listed in the 2013-14 file, some districts were not assigned a locale code. These districts were omitted from the analyses; they represented less than $0.3 \%$ of all school districts. Another minor shortcoming to this one-year lag is the possibility that some district locales may have been reclassified, but again the potential effect is minimal.

Pie charts were formed using counts of districts by locale code for each jurisdiction. To move from granular data to a more summarizing figure, locale codes were collapsed into four categories: urban, suburban, town, and rural. This follows the convention used in other NCES products, such as the Schools and Staffing Survey. Districts were then counted by collapsed locale type for each entity. Only "regular" LEAs (labeled type 1 or type 2) were included in the tally, matching the method used by NCES in their Digest of Education Statistics. This tally excludes charteronly districts and state-operated specialized agencies. Assignment to each state or jurisdiction was made based on the Federal Information Processing Standard (FIPS) code rather than physical location, as Department of Defense (DOD) and Bureau of Indian Education (BIE) school systems located within the states are under a separate authority. From the counts of regular LEAs by locale type, pie charts were generated for each state except Hawaii, as it has only one LEA. The chart for DC was omitted for the same reason, and Guam and the Northern Mariana Islands do not have pie charts because no locale codes are assigned to these territories by NCES. 
University of Pennsylvania

3440 Market Street, Suite 560

Philadelphia, PA 19104

Tel: 215.573.0700

CONSORTIUMforPOLICY RESEARCHinEDUCATION

cpre.org

\section{State Leadership Development Policies}

An Analysis of 50 States and Territories
About Consortium for Policy Research in Education The Consortium for Policy Research in Education (CPRE) brings together education experts from renowned research institutions to contribute new knowledge that informs education policy and practice. CPRE conducts research; connects policymakers and practitioners to evidence-based knowledge and research findings; and collaborates with policymakers, practitioners, and researchers to improve education policy and practice. Our work is peer reviewed and open access. To learn more, visit cpre.org.

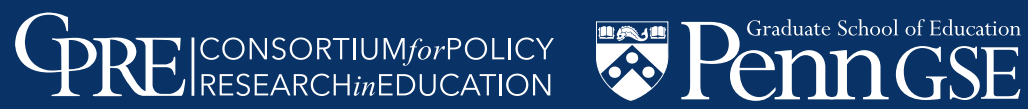

About National Association of State Boards of Education The National Association of State Boards of Education (NASBE) is a nonprofit, private association that represents state and territorial boards of education. Its principal objectives are to strengthen state leadership in education policymaking, promote excellence in the education of all students, advocate equality of access to educational opportunity, and ensure continued citizen support for public education. To learn more, visit nasbe.org

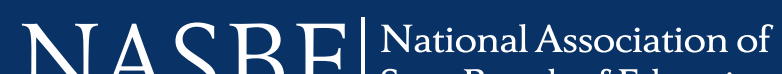

